\title{
Expression of Pluripotency and Oocyte-Related Genes in Single Putative Stem Cells from Human Adult Ovarian Surface Epithelium Cultured In Vitro in the Presence of Follicular Fluid
}

\author{
Irma Virant-Klun, ${ }^{1}$ Thomas Skutella, ${ }^{2}$ Mikael Kubista, ${ }^{3,4}$ Andrej Vogler, ${ }^{1}$ \\ Jasna Sinkovec, ${ }^{1}$ and Helena Meden-Vrtovec ${ }^{1}$ \\ ${ }^{1}$ Department of Obstetrics and Gynecology, University Medical Centre Ljubljana, Slajmerjeva 3, 1000 Ljubljana, Slovenia \\ ${ }^{2}$ Institute for Anatomy and Cell Biology, Medical Faculty, University of Heidelberg, Im Neuenheimer Feld 307, \\ 69120 Heidelberg, Germany \\ ${ }^{3}$ TATAA Biocenter AB, Odinsgatan 28, 41103 Göteborg, Sweden \\ ${ }^{4}$ Institute of Biotechnology AS CR, Lb Building, 14220 Prague, Czech Republic
}

Correspondence should be addressed to Irma Virant-Klun; irma.virant@gmail.com

Received 30 October 2012; Accepted 24 December 2012

Academic Editor: Deepa Bhartiya

Copyright (c) 2013 Irma Virant-Klun et al. This is an open access article distributed under the Creative Commons Attribution License, which permits unrestricted use, distribution, and reproduction in any medium, provided the original work is properly cited.

\begin{abstract}
The aim of this study was to trigger the expression of genes related to oocytes in putative ovarian stem cells scraped from the ovarian surface epithelium of women with premature ovarian failure and cultured in vitro in the presence of follicular fluid, rich in substances for oocyte growth and maturation. Ovarian surface epithelium was scraped and cell cultures were set up by scrapings in five women with nonfunctional ovaries and with no naturally present mature follicles or oocytes. In the presence of donated follicular fluid putative stem cells grew and developed into primitive oocyte-like cells. A detailed single-cell gene expression profiling was performed to elucidate their genetic status in comparison to human embryonic stem cells, oocytes, and somatic fibroblasts. The ovarian cell cultures depleted/converted reproductive hormones from the culture medium. Estradiol alone or together with other substances may be involved in development of these primitive oocyte-like cells. The majority of primitive oocyte-like cells was mononuclear and expressed several genes related to pluripotency and oocytes, including genes related to meiosis, although they did not express some important oocyte-specific genes. Our work reveals the presence of putative stem cells in the ovarian surface epithelium of women with premature ovarian failure.
\end{abstract}

\section{Introduction}

From the literature it is known that oocyte-like cells expressing different oocyte-specific genes can be developed in vitro from mouse embryonic stem cells (mESCs) [1-8], human embryonic stem cells (hESCs) or human induced pluripotent stem cells (hiPSCs) [9-11], stem cells from human amniotic fluid [12], from porcine fetal skin [13, 14], and even from rat pancreatic stem cells [15].

Although in vitro oogenesis from animal and human ESCs could represent a model to study the mechanisms of oogenesis and their pathologies, the potential oogenesis from the autologous ovarian stem cells would be of great advantage because it may be realistically applied in human medicine in the future. Ovarian stem cells may play an important role. More studies have already confirmed the presence of pluripotent/multipotent stem cells in neonatal and adult ovaries of mice $[6,16,17]$ and proposed human ovarian surface epithelium (OSE) as an important source of stem cells in human [18-22] and other mammalian species, such as sheep and monkey [22]. Moreover, White et al. have recently published the existence of rare mitotically active cells-germline stem cells-with a gene expression profile that is consistent with primitive germ cells, which can be purified from adult human ovarian cortical tissue by fluorescence-activated cell sortingbased protocol [23]. They have proven that these cells can 
be expanded for months in vitro and can spontaneously be developed into haploid oocyte-like cells with diameters of up to $35-50 \mu \mathrm{m}$. When marked with green fluorescence protein (GFP) and transplanted into human ovarian cortical biopsies, the follicles containing GFP-positive oocytes were formed 12 weeks after the xenotransplantation into immunodeficient female mice. They concluded that the ovaries of reproductiveage women possess rare mitotically active germ cells that can be propagated in vitro and can generate oocytes in vitro and in vivo.

Premature ovarian failure (POF) is one of the most serious indications of female infertility resulting in nonfunctional ovaries without mature follicles and oocytes before the age of 40 years [24]. It is characterized by high levels of gonadotropins in the blood and amenorrhea. These women have no mature oocytes and do not conceive and cannot bear their own child. Any potential to regenerate the nonfunctional ovaries in these women would be of the greatest importance in reproductive medicine.

The aim of this study was to culture in vitro putative stem cells from the OSE of nonfunctional ovaries in the presence of donated follicular fluid, rich in substances important for oocyte growth and maturation to trigger their growth and the expression of genes related to human oocytes. Because the genetic status of oocyte-like cells developed in vitro from stem cells is still poorly understood, these cells were analyzed by detailed single-cell gene expression profiling in comparison to human embryonic stem cells, oocytes at different stages of maturity, and somatic fibroblasts to elucidate their genetic status. In this way we made some steps further from our previous work. The primitive oocyte-like cells developed in this study expressed several genes characteristic of pluripotent stem cells and oocytes, including some genes related to meiosis, but were more "stem cells" than "oocytes" at this stage.

\section{Materials and Methods}

In five women with premature ovarian failure (POF) and with no naturally present mature follicles or oocytes the putative ovarian stem cells were retrieved by OSE brushing. The mean female age was 34 years (range: 21-39 years). Each woman donated a part of her ovarian tissue for the purpose of research after having the study explained in detail and then provided written consent to participate. All women were characterized by irregularities in their menstrual cycle, elevated levels of gonadotropins (follicle-stimulating hormone $(\mathrm{FSH})$ and luteinizing hormone (LH)) in their blood serum, and a thin endometrium, as can be seen in Table 1. The molecular status of oocyte-like cells developed in vitro was compared to hESCs (H1 cell line, WiCell Research Institute, Madison, WI, USA) and nonfertilized oocytes from the in vitro fertilization programme, donated for the purpose of research with the written consents of the donating women. There was no financial recompense to the donors of oocytes. This research was approved by the Slovenian Medical Ethical Committee (Ministry of Health of the Republic of Slovenia, No. 110/10/05).
2.1. Ovarian Stem Cell Retrieval. In each of the five women with POF the putative ovarian stem cells were retrieved by soft OSE brushing of the whole ovary and small ovarian cortex biopsy (approximately $0.3 \mathrm{~mm}^{3}$ ), retrieved by the usual diagnostic laparoscopic procedure. A part of the ovarian cortex biopsy was sent to the histopathological service lab to evaluate the presence of follicles or oocytes after haematoxylin-eosin (HE) staining, common in everyday clinical practice; another part of the ovarian cortex tissue was used to set up a cell culture. The ovarian cortex biopsy was put in a volume of $2.5 \mathrm{~mL}$ of warmed and preincubated supplemented DMEM/F-12 culture medium (composition described below). The OSE layer was mechanically scraped several times using a sterile surgical blade (Swann-Morton, Sheffield, United Kingdom, ref. 0501), which was washed in the surrounding culture medium to retrieve a scraped suspension of cells to set up cell cultures.

2.2. Ovarian Surface Epithelium Cell Culture. The OSE cell cultures were set up using OSE brushings of cortex biopsies. In each patient the OSE cell culture was set up by dropping five drops of the cell suspension from brushed OSE into the DMEM/F-12 culture medium, prepared as follows: Dulbecco's Modified Eagle's Medium (DMEM)/Nutrient Mixture F-12 Ham with L-glutamine, phenol red, and 15 mM HEPES (Sigma Aldrich), supplemented with $3.7 \mathrm{~g} / \mathrm{L} \mathrm{NaHCO}_{3}, 1 \%$ penicillin/streptomycin, and $0.5 \%$ gentamycin, and with the $\mathrm{pH}$ adjusted to 7.4 with $1 \mathrm{M} \mathrm{NaOH}$; this culture medium was supplemented with $20 \%(\mathrm{v} / \mathrm{v})$ donated follicular fluid from the in vitro fertilization programme. In each patient the cell culture was set up in 12 IVF Multidish Four well Nunclon dishes (Nunc, Roskilde, Denmark, ref. 144444). Each well was filled with $350 \mu \mathrm{L}$ of preincubated culture medium to which drops of the cell suspension from brushed OSE were added. The cells were cultured for two months in a $\mathrm{CO}_{2}$ incubator (Heraeus 6000, Heraeus Holding, Hanau, Germany) at $37^{\circ} \mathrm{C}$ and $6 \% \mathrm{CO}_{2}$ in the air and monitored daily under a heatstaged inverted microscope (ECLIPSE 2000-S, Nikon, Tokyo, Japan) equipped with a Digital Sight camera (Nikon, Tokyo, Japan).

2.3. Preparation of Follicular Fluid. The follicular fluid, retrieved after the written consent of the young donor who had normal ovarian function, was used immediately after the removal of the oocytes (to be fertilized in vitro) in order not to coagulate. It was centrifuged for 10 minutes at 2,500 rpm $(349 \times \mathrm{g})$. The supernatant was filtered through a sterile Sartorius Minisart $0.45 \mu \mathrm{m}$ filter to remove all the cells. The filtered supernatant was heat inactivated at $56^{\circ} \mathrm{C}$ for 45 minutes. Then it was aliquoted and stored at $-20^{\circ} \mathrm{C}$ until its use. When it was used, an aliquot of prepared follicular fluid was thawed at the room temperature and added to the culture medium. This fluid contained substances important for oocyte growth and differentiation and was added to provide an ovarian-like growth milieu.

2.4. Analyses of Reproductive Hormones in Culture Medium. In the samples of culture medium with added follicular 
TABLE 1: Clinical data of all five patients with POF included into this study, which were documented at the Department of Obstetrics and Gynecology, University Medical Centre Ljubljana. All patients had increased serum levels of gonadotropins FSH (normal: <11.3 IU/L) and LH (normal: <11.6 IU/L) and thin endometrium.

\begin{tabular}{|c|c|c|c|c|c|}
\hline \multirow[b]{2}{*}{ Clinical data } & \multicolumn{5}{|c|}{ Patients } \\
\hline & $\begin{array}{c}\text { P1 } \\
\text { (R.A.) }\end{array}$ & $\begin{array}{c}\text { P2 } \\
\text { (G.K.) }\end{array}$ & $\begin{array}{c}\text { P3 } \\
\text { (M.S.) }\end{array}$ & $\begin{array}{c}\text { P4 } \\
\text { (G.A.) }\end{array}$ & $\begin{array}{c}\text { P5 } \\
\text { (P.R.A.) }\end{array}$ \\
\hline Age (years) & 39 & 40 & 21 & 31 & 39 \\
\hline FSH (IU/L) & 89.1 & 65.8 & 11.8 & 162.0 & 67.8 \\
\hline LH (IU/L) & 23.3 & 23.4 & 10.1 & 59.0 & 37.8 \\
\hline Prolactin (mg/L) & 12 & 4.6 & 16.4 & 9.3 & l \\
\hline Estradiol (nmol/L) & $<0.073$ & 0.08 & 0.2 & I & l \\
\hline Inhibin B (ng/L) & $<10$ & $<10$ & 52.4 & $>10$ & l \\
\hline S-AMH (mg/L) & 0.00 & 0.00 & 0.89 & 0.00 & l \\
\hline Karyotype & $\begin{array}{c}\text { Abnormal } \\
\text { (mosaic 45X, } \\
\text { 47XXX, 48XXXX, } \\
\text { 46XX) }\end{array}$ & $\begin{array}{c}\text { Normal } \\
\text { (no FMR1-fragile X } \\
\text { mutation) }\end{array}$ & $\begin{array}{c}\text { Normal } \\
\text { (no FMR1-fragile X } \\
\text { mutation) }\end{array}$ & $\begin{array}{c}\text { Normal } \\
\text { (no FMR1-fragile X } \\
\text { mutation) }\end{array}$ & $\begin{array}{c}\text { Normal } \\
\text { (no FMR1-fragile X } \\
\text { mutation) }\end{array}$ \\
\hline $\begin{array}{l}\text { Ovarian cortex } \\
\text { histology }\end{array}$ & $\begin{array}{l}\text { Inclusion cysts, } \\
\text { corpora albicantia, } \\
\text { focal ovarian } \\
\text { surface epithelium, } \\
\text { no follicles or } \\
\text { oocytes }\end{array}$ & $\begin{array}{l}\text { Inclusion cysts, } \\
\text { corpora albicantia, } \\
\text { simple or stratified } \\
\text { ovarian surface } \\
\text { epithelium, no } \\
\text { follicles or oocytes }\end{array}$ & $\begin{array}{l}\text { Simple columnar } \\
\text { ovarian surface } \\
\text { epithelium, several } \\
\text { primordial follicles }\end{array}$ & $\begin{array}{l}\text { Simple cuboidal } \\
\text { ovarian surface } \\
\text { epithelium, corpus } \\
\text { luteum in } \\
\text { regression, no } \\
\text { follicles or oocytes }\end{array}$ & $\begin{array}{l}\text { Simple cuboidal } \\
\text { ovarian surface } \\
\text { epithelium, } \\
\text { no follicles or } \\
\text { oocytes }\end{array}$ \\
\hline $\begin{array}{l}\text { Antiovarian } \\
\text { antibodies }\end{array}$ & No & No & Yes & Yes & No \\
\hline $\begin{array}{l}\text { Premature ovarian } \\
\text { failure (POF) }\end{array}$ & $\begin{array}{c}\text { Secondary } \\
\text { (previous birth of a } \\
\text { child), } \\
\text { irregularities of } \\
\text { menstrual cycles, } \\
\text { thin endometrium }\end{array}$ & $\begin{array}{c}\text { Primary } \\
\text { (no children), } \\
\text { irregular menstrual } \\
\text { cycles, thin } \\
\text { endometrium }\end{array}$ & $\begin{array}{c}\text { Primary } \\
\text { (no children), } \\
\text { irregular menstrual } \\
\text { cycles, thin } \\
\text { endometrium }\end{array}$ & $\begin{array}{c}\text { Primary } \\
\text { (no children), } \\
\text { amenorrhea, small } \\
\text { left ovary, thin } \\
\text { endometrium }\end{array}$ & $\begin{array}{c}\text { Secondary } \\
\text { (pregnancy ended } \\
\text { in spontaneous } \\
\text { abortion), } \\
\text { amenorrhea, thin } \\
\text { endometrium }\end{array}$ \\
\hline
\end{tabular}

fluid which were taken from two different OSE cell cultures after 15-17 days of culturing the concentrations of estradiol, progesterone, androstenedione, and testosterone were measured in comparison with the same medium with added follicular fluid and without cell culture and the same medium without follicular fluid and without cell culture. Estradiol was measured by a chemoluminescent, competitive, immunochemical method by reagents (Immulite, Siemens, USA) which included alkaline phosphatase-conjugated estradiol and highly specific polyclonal rabbit antiestradiol antibodies on paramagnetic particles. Progesterone was measured by a chemoluminescent, noncompetitive, immunochemical method by reagents (Immulite, Siemens, USA) which included alkaline phosphatase-conjugated progesterone and highly specific monoclonal rabbit antiprogesterone antibodies on paramagnetic particles. Both hormones were analyzed by Immulite analyzer (Siemens, USA). Androstenedione was measured by a specific double antibody RIA using 125 Ilabeled hormones (Diagnostic Systems Laboratories, Webster, TX, USA). Testosterone level was determined by RIA (DiaSorin and DPC, Los Angeles, CA, USA). All procedures were performed according to standardized procedures at the Institute of Nuclear Medicine, University Medical Centre Ljubljana.
2.5. Single-Cell Gene Expression Analyses Using the Fluidigm BioMark System. Gene expression analyses of single oocytelike cells in comparison with single hESCs and groups of five, ten, and twenty hESCs of $\mathrm{H} 1$ line (positive controls), single nonfertilized oocytes from the in vitro fertilization programme (positive controls), and single human fibroblasts and groups of five, ten, and twenty fibroblasts of F161 line (negative controls) were performed using the BioMark Real-Time quantitative PCR (qPCR) system (Fluidigm, San Francisco, CA, USA). In all oocyte-like cells, mechanically removed from the cell cultures expressions of 56 genes, 21 genes characteristic of pluripotent stem cells (KIT, KIT LIG, OCT4A, NANOG, MYC, KLF4, SOX-2, UTF1, TDGF1, LIN28B, TERT, CD9, LIN28, NANOS, CDH1, STAT3, REX1, MEST, CRKRS, STELLA, and GDF3) and 34 genes typical of oocytes (VASA, DAZL, STELLA, GFRa1, KIT, KIT LIG, DNMT3B, DNMT1, BMP15, ZP1, ZP2, ZP3, ZP4, SCP1, SCP2, SCP3, BUB1, BUB3, NOBOX, MSH5, NLRP5, FMN2, HIFOO, MLH1, ZAR1, REC8, PRDM1/BLIMP1, FIGLA, STAG3, DMC1, SMC1, CD9, $B N C 1$, and CCNB1) and of the housekeeping gene GAPDH were analyzed. The inventoried TaqMan assays (20x, Applied Biosystems, Life Technologies, Carlsbad, CA, USA) were pooled to a final concentration of $0.2 \mathrm{x}$ for each of the 56 assays. The cells to be analyzed were harvested directly into 
$9 \mu \mathrm{L}$ RT-PreAmp Master Mix: 5.0 $\mu$ L CellsDirect 2x Reaction Mix (Invitrogen, Life Technologies, Carlsbad, CA, USA); $2.5 \mu \mathrm{L} 0.2 \mathrm{x}$ assay pool; $0.2 \mu \mathrm{L}$ RT/Taq Superscript III (Invitrogen, Life Technologies); $1.3 \mu \mathrm{L}$ TE buffer. The harvested cells were immediately frozen and stored at $-80^{\circ} \mathrm{C}$. Cell lysis and sequence-specific reverse transcription were performed at $50^{\circ} \mathrm{C}$ for 15 minutes. The reverse transcriptase was inactivated by heating to $95^{\circ} \mathrm{C}$ for 2 minutes. Subsequently, in the same tube cDNA went through limited sequence-specific amplification by denaturing at $95^{\circ} \mathrm{C}$ for 15 seconds and then annealing and amplification at $60^{\circ} \mathrm{C}$ for four minutes for 14 cycles. These preamplified products were diluted 5-fold prior to analysis with the Universal PCR Master Mix and inventoried TaqMan gene expression assays (ABI) in 96.96 Dynamic Arrays on a BioMark System. Each sample was analyzed in two technical replicates. Ct values obtained from the BioMark System were transferred to the GenEx software (MultiD) to analyze the gene expressions.

2.6. Analyses of Single-Cell Gene Expressions by GenEx Software (MultiD). Ct values were obtained from the BioMark System and transferred to the GenEx software (MultiD Analyses, Göteborg, Sweden). Missing data in the BioMark System were given a Ct of 999. These were removed in GenEx. Also Ct values larger than 25 were removed (cut-off value > 25), since samples with such high Ct values in the BioMark $96 \times 96$ microfluidic card were expected to be negative, and these readings were unreliable. Technical repeats were then averaged. Missing data were then replaced by the highest $\mathrm{Cq}$ +1 for each gene. This corresponded to assigning a concentration to these samples that was half of the lowest concentration measured and was motivated by sampling ambiguity. There was also a need to handle missing data for downstream classification with multivariate tools. Linear quantities were calculated relative to the sample having lowest expression, and data were converted to $\log _{2}$ scale. Because of single-cell gene expression analyses, normalization to the housekeeping genes was not performed. The data were now prepared for multivariate analysis to classify the samples based on the combined expression of all the genes. Heatmap clustering (Ward's Algorithm, Euclidean Distance Measure), hierarchical clustering (Ward's Algorithm, Euclidean Distance Measure), and principal component analysis (PCA) were performed. In addition, descriptive statistics were calculated individually for the genes using a $0.95 \%$ confidence level, and groups were compared using 1-way ANOVA (Tukey-Kramer's pairwise comparison) and unpaired 2-tailed $t$-test. According to Dunn-Bonferroni, corrected statistical significance was set at $P<0.00244$ for genes of pluripotency or $P<0.00151$ for oocyte-specific genes to account for false positives due to multiple testing.

2.7. DAPI Staining of Cell Nuclei. To monitor the cell nuclei, single oocyte-like cells were isolated from the cultures and put into a drop of Vectashield mounting medium for fluorescence with DAPI (Vector Laboratories, Peterborough, United Kingdom) and observed under a fluorescence microscope (ECLIPSE E-600 with a Digital Sight camera, magnifications of 200/400x, Nikon, Tokyo, Japan) after 20 minutes of incubation at the room temperature and in the dark.

\section{Results}

3.1. Histopathology of Ovarian Tissue. A part of each ovarian cortex biopsy was sent to the histopathological routine service. In four of them no follicles or oocytes were observed in their ovarian cortex, and in one biopsy only a few primordial follicles were found after haematoxylin-eosin (HE) staining (Figure 1). Cytokeratin (CK7) staining revealed the presence of OSE in all five ovarian biopsies.

3.2. In Vitro Culture of Scraped Ovarian Surface Epithelium. Ovarian fibroblasts were the first cells to attach to the bottom of the dish. They were observed from approximately the second day of culture as elongated cells spreading the dish bottom. After five days, the first large, round cells with different diameters appeared in the culture (Figures 2(a) and 2(b)). Most of them grew attached to the autologous ovarian fibroblasts (Figure 2(c)). The largest cells had diameters of 50$60 \mu \mathrm{m}$ and had different granularity to their cytoplasm. Some of them had low-granular cytoplasm and resembled primitive oocytes (Figures 2(d) and 2(e)). Henceforth, we refer to them as primitive oocyte-like cells. Rarly they developed zona pellucida-like structures (Figure 2(f)). Some of them developed into parthenogenetic blastocyst-like structures, as can be seen in Figure 3 (OLC18). The primitive oocyte-like cells that developed showed no signs of degeneration during extended cell culturing of up to two months and retained the round shape.

3.3. Concentrations of Reproductive Hormones in Culture Medium. All samples of culture medium with added follicular fluid were characterized by very high concentrations of estradiol and progesterone in comparison with reference serum values during different phases of female menstrual cycle (Table 2). They also contained significant concentrations of androstenedione and testosterone in comparison with culture medium without added follicular fluid. In samples of culture medium from ovarian cell cultures the concentrations of all hormones were lower than in samples with added follicular fluid, but without ovarian cell culture; these hormones were depleted/converted by ovarian cell cultures. Also a pure culture medium without added follicular fluid contained a low level of estradiol thus reflecting the presence of phenol red, which is known to express weak estrogenic activity in tissue culture media [25].

3.4. Characterization of Individual Primitive Oocyte-Like Cells Differentiated In Vitro by Expression Profiling of Pluripotent Stem Cell and Oocyte-Specific Genes. In samples from all patients who had no follicles or oocytes in their ovarian cortex, 18 primitive oocyte-like cells differentiated in vitro (Figure 3) and cultured for up to one month (from 5 to 31 days) were mechanically removed from the culture with a glass pipette. Expression of 56 genes was measured in each 

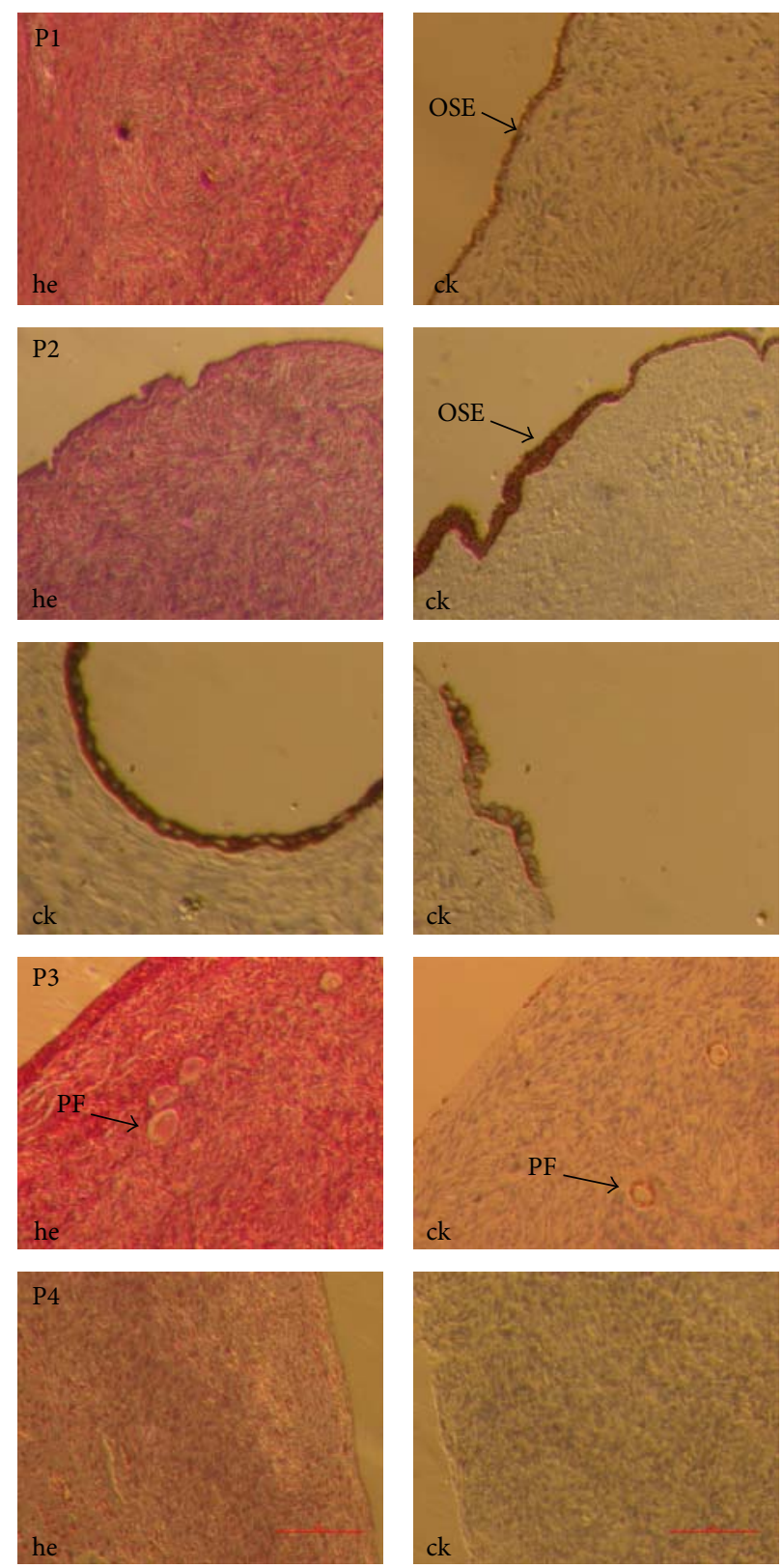

FIGURE 1: Histology of ovarian sections after haematoxylin-eosin (he) and cytokeratin (ck) stainings in patients (P1, P2, P3, and P4) with POF. It confirmed no naturally present follicles or oocytes in their ovarian cortex, except for primordial follicles in P3. In P5 the histology has been performed in another medical institution. (inverted microscope, Hoffman, magnification 40/100x.) Legend: OSE: ovarian surface epithelium (brown stained), PF: primordial follicle.

primitive oocyte-like cell. Twenty-one genes were characteristic of pluripotent stem cells, 34 genes were typical of oocytes, and one gene was housekeeping gene (see Section 2). Nineteen individual nonfertilized oocytes from the in vitro fertilization programme collected at different stages of maturation (six germinal vesicle $(\mathrm{GV})$, four metaphase I-MI, four metaphase II-MII, and five in vitro matured(IVM) oocytes) and hESCs of the H1 line (three single cells, a group of five cells, a group of ten cells, and a group of twenty cells) were used as positive controls, and human adult fibroblasts from the F161 line (three single cells, a group of five cells, a group of ten cells, and a group of twenty cells) were used as negative controls.

3.4.1. Comparison of Gene Expression Profiles for All Analyzed Genes in All Analyzed Types of Cells. Different types of cells express different genes, and when comparing the expression among the cells we analyze, we expected to see significant differences (Figure 4). There is substantial natural variation in the transcript levels of individual cells of the same kind because of temporal fluctuations caused by transcriptional bursting [26, 27]. The cells of different kinds cannot be 


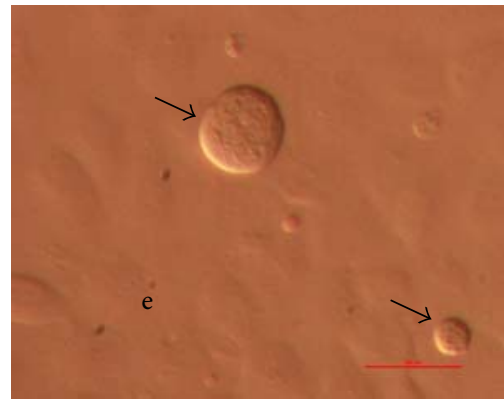

(a)

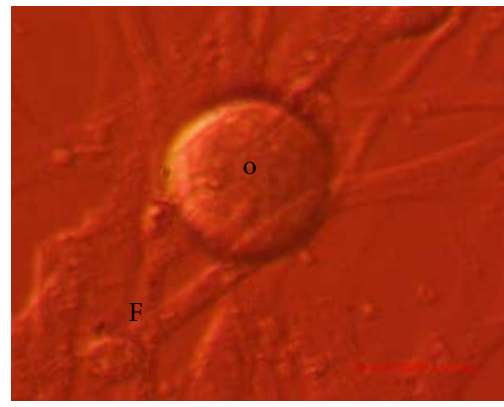

(c)

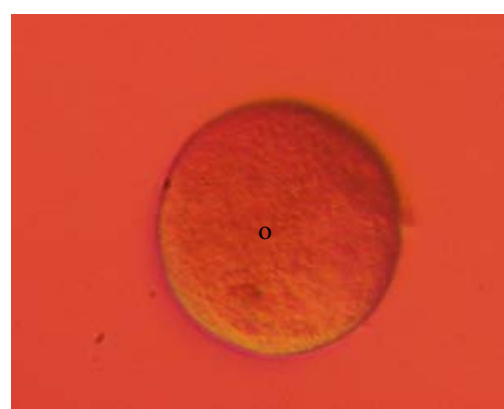

(e)

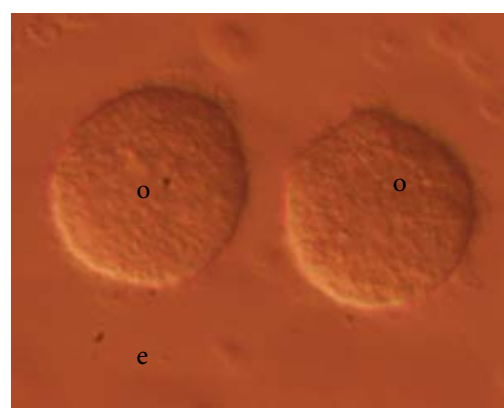

(g)

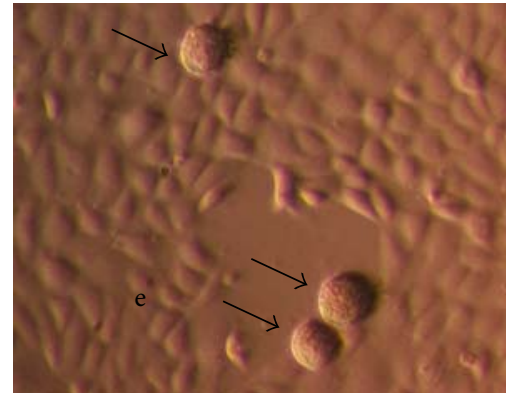

(b)

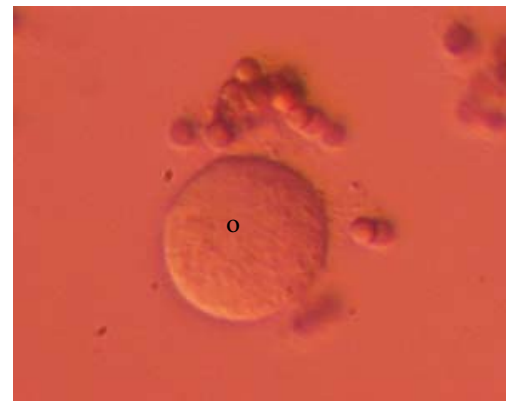

(d)

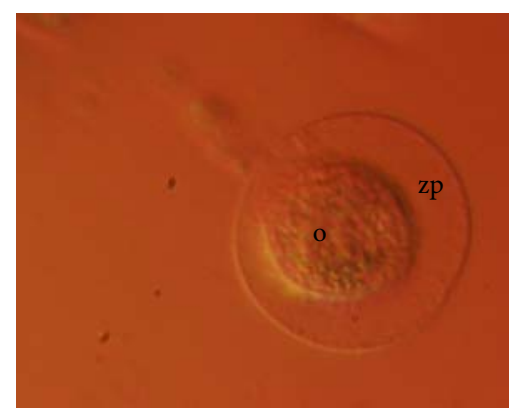

(f)

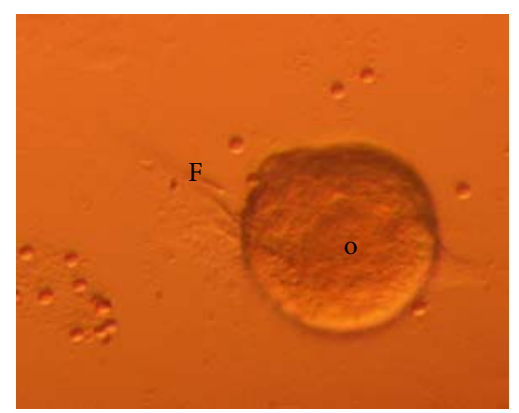

(h)

Figure 2: Primitive oocyte-like cells (arrows) developing in ovarian surface epithelium cell cultures set up by ovarian cortex biopsy scrapings: $(\mathrm{a}, \mathrm{b})$ among epithelial cells, (c) attached to autologous ovarian fibroblasts, (d, e) oocyte-like cells, (f) growing primitive oocyte-like cell with zona pellucida-like structure, $(\mathrm{g})$ oocyte-like cells, and (h) primitive oocyte-like cell attached to fibroblast. Scale bars: $(\mathrm{a}, \mathrm{b}) 100 \mu \mathrm{m},(\mathrm{c}-\mathrm{h})$ $50 \mu \mathrm{m}$. Legend: e: epithelial cells, F: fibroblast, o: oocyte-like cell, and zp: zona pellucida-like structure. 
TABLE 2: The mean concentrations of reproductive hormones in samples of culture medium (DMEM/F-12) with added follicular fluid (FF). Retrieved from two different ovarian cell cultures (OSE) with developing oocyte-like cells after 15-17 days of culturing in comparison with the same culture medium with added follicular fluid (without OSE cell culture) and the same culture medium (without added follicular fluid and OSE cell culture).

\begin{tabular}{|c|c|c|c|c|}
\hline & \multicolumn{4}{|c|}{ Concentrations of hormones in culture medium } \\
\hline & $\begin{array}{l}\text { Estradiol* }^{*} \\
(\mathrm{nmol} / \mathrm{L})\end{array}$ & $\begin{array}{l}\text { Progesterone }{ }^{* *} \\
\text { (nmol/L) }\end{array}$ & $\begin{array}{l}\text { Androstenedione } \\
(\mathrm{nmol} / \mathrm{L})\end{array}$ & $\begin{array}{l}\text { Testosterone } \\
(\mathrm{nmol} / \mathrm{L})\end{array}$ \\
\hline $\begin{array}{l}\text { DMEM/F-12 } \\
+ \text { FF } \\
+ \text { OSE } \\
\text { (min.-max.) }\end{array}$ & $\begin{array}{c}175.5 \\
(149.0-202.0)\end{array}$ & $\begin{array}{c}1473.5 \\
(3999.0-1052.0)\end{array}$ & $\begin{array}{c}81.4 \\
(82.5-80.3)\end{array}$ & $\begin{array}{c}2.55 \\
(2.4-2.7)\end{array}$ \\
\hline $\begin{array}{l}\text { DMEM/F-12 + FF } \\
\text { (min.-max.) }\end{array}$ & $\begin{array}{c}310.5 \\
(377.0-244.0)\end{array}$ & $\begin{array}{c}4783.5 \\
(5528.0-4039.0)\end{array}$ & $\begin{array}{c}91.4 \\
(90.1-92.8)\end{array}$ & $\begin{array}{c}4.15 \\
(3.9-4.4)\end{array}$ \\
\hline $\begin{array}{l}\text { DMEM/F-12 } \\
\text { (min.-max.) }\end{array}$ & $\begin{array}{c}0.73 \\
(0.66-0.81)\end{array}$ & $<0.64$ & $\begin{array}{c}0.015 \\
(0.01-0.02)\end{array}$ & $\begin{array}{c}1.1 \\
(1.0-1.2)\end{array}$ \\
\hline
\end{tabular}

${ }^{*}$ Reference serum values in women. Follicular phase: $0-0.59 \mathrm{nmol} / \mathrm{L}$; follicular phase, day 2-3: 0-0.31 nmol/L; at ovulation: $0.12-1.47 \mathrm{nmol} / \mathrm{L}$; luteal phase: $0.1-$ $0.9 \mathrm{nmol} / \mathrm{L}$; nontreated postmenopausal: $0-0.11 \mathrm{nmol} / \mathrm{L}$; treated postmenopausal: $0-0.34 \mathrm{nmol} / \mathrm{L}$; at oral contraception: $0-0.37 \mathrm{nmol} / \mathrm{L}$. Reference serum value in men: $0-0.21 \mathrm{nmol} / \mathrm{L}$.

${ }^{* *}$ Reference serum values in women. Follicular phase: up to $3.6 \mathrm{nmol} / \mathrm{L}$; follicular phase, middle: up to $3.1 \mathrm{nmol} / \mathrm{L}$; at ovulation: $1.5-5.5 \mathrm{nmol} / \mathrm{L}$; luteal phase: $3.0-68 \mathrm{nmol} / \mathrm{L}$; luteal phase, middle: $19-76 \mathrm{nmol} / \mathrm{L}$; postmenopausal: up to $3.2 \mathrm{nmol} / \mathrm{L}$; at oral contraception: $1.1-2.9 \mathrm{nmol} / \mathrm{L}$; pregnancy, first quarter: $29.6-$ $106 \mathrm{nmol} / \mathrm{L}$; pregnancy, second quarter: $93.8-159 \mathrm{nmol} / \mathrm{L}$; pregnancy, third quarter: $264-509 \mathrm{nmol} / \mathrm{L}$. Reference serum value in men: $0.86-2.9 \mathrm{nmol} / \mathrm{L}$.
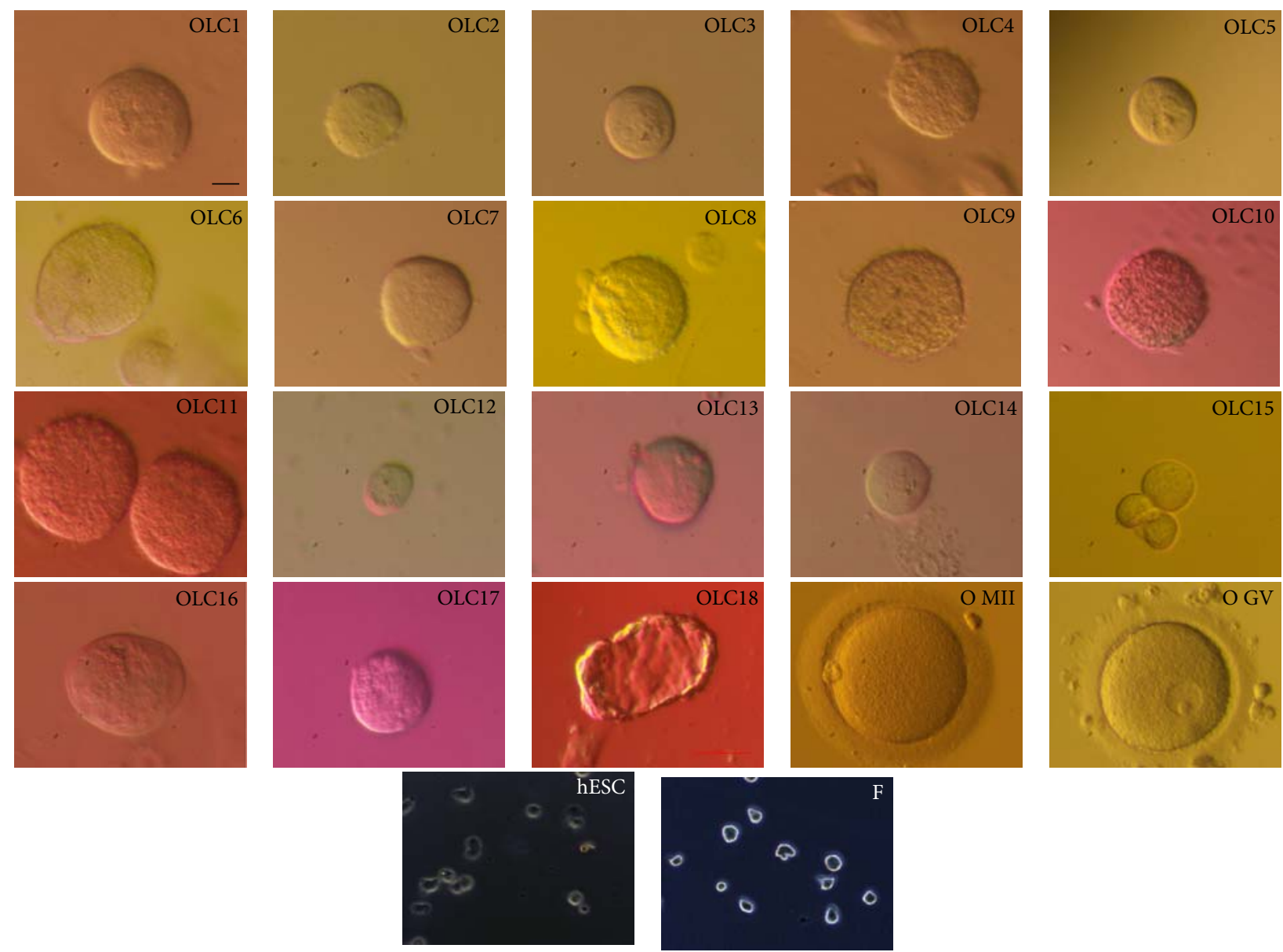

FIGURE 3: Single cells analyzed on expression of genes: eighteen single primitive oocyte-like cells (OLC1-18), developed in vitro (OLC18 further developed in a parthenogenetic blastocyst-like structure) and cultured for up to one month (OLC1-8 and OLC16-18 for 15 days, OLC9-11 for 30 days, and OLC12-15 for 5 days), one mature (O MII) and one immature (O GV) oocyte (inverted microscope, Hoffman, scale bar: $10 \mu \mathrm{m}$ ), and human embryonic stem cells (hESCs) and fibroblasts (F) under a phase-contrast microscope (magnification 200x). 


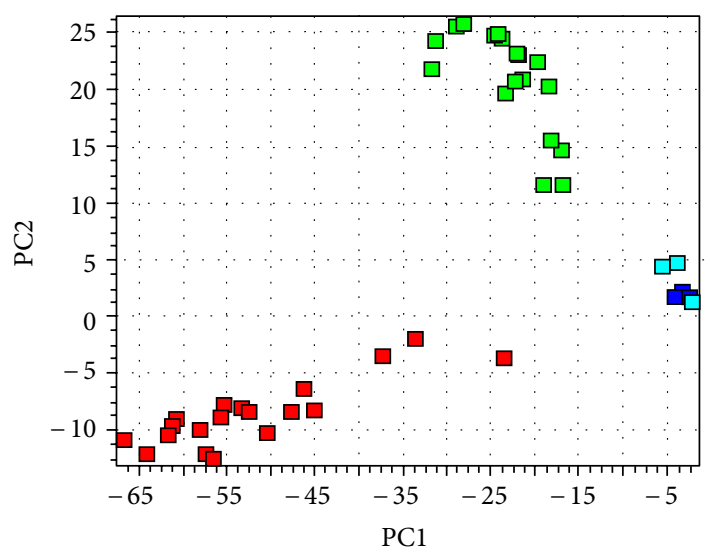

(a)

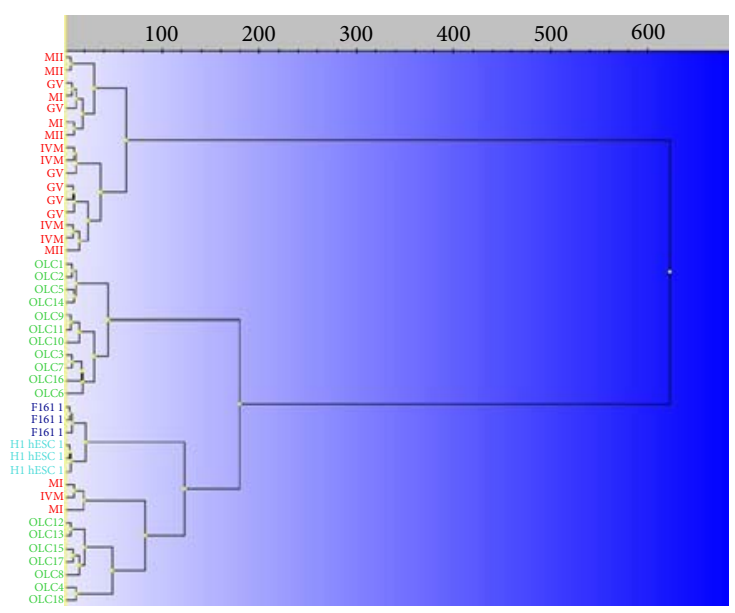

(c)

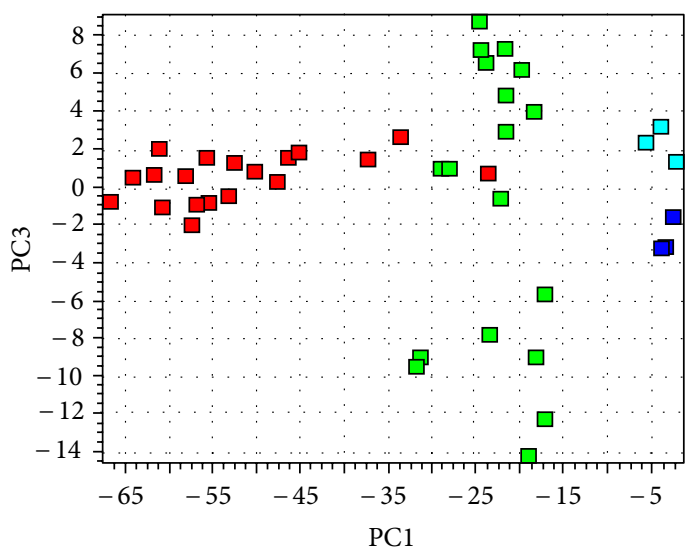

(b)
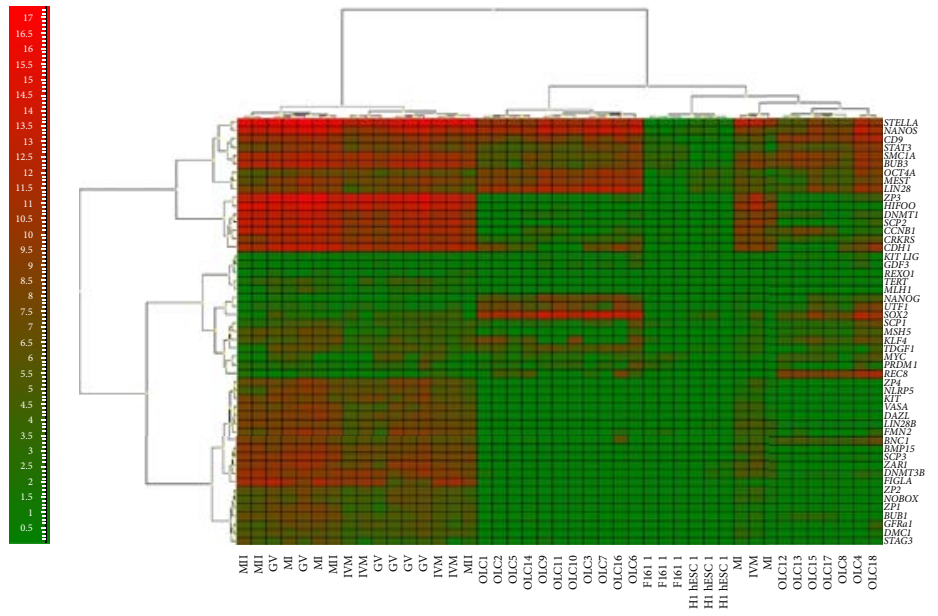

(d)

FIGURE 4: Single-cell gene expression profile of all analyzed genes in primitive oocyte-like cells developed in vitro (OLCs). Comparison with human embryonic stem cells (H1 hESCs), nonfertilized oocytes from the in vitro fertilization programme (O) and fibroblasts (F161) revealed the expression of several genes related to pluripotent stem cells and oocytes. (a) Principle component analysis (PC1 versus PC2). (b) Principle component analysis (PC2 versus PC3). (c) Hierarchical clustering. (d) Heatmap clustering. Legend of analyzed cells:OLC(1-18): primitive oocyte-like cells developed in vitro; O: oocytes; H1 hESC: human embryonic stem cells of line H1 (1: one cell, 5: five cells, 10: ten cells, and 20: twenty cells); F161: fibroblasts of F161 line (1: one cell, 5: five cells, 10: ten cells, 20: twenty cells); MII: mature, metaphase II oocytes; IVM: immature, in vitro matured oocytes; MI: immature, metaphase I oocytes; GV: immature, germinal vesicle oocytes from the in vitro fertilization programme. Cell group colours: red: oocytes from the in vitro fertilization programme, green: primitive oocyte-like cells, developed in vitro, aquamarine: hESCs, and dark blue: fibroblasts.

unambiguously distinguished based on the expression of any individual gene; it is rather more effective to separate them based on the correlated expression of the panel of genes [28]. The most common and powerful tools to categorize samples based on the expression of multiple genes are the principle component analysis (PCA) and hierarchical clustering [29]. PCA identifies the combinations of genes that account for most of the variation in the measured data and can be used to visually cluster samples based on similar expression profiles in a scatter plot with axes that represent those optimal linear combinations of genes. Those optimum combinations are called principal components (PCs). Figure 4(a) shows all the analyzed single-cell samples clustered in a PC1 versus PC2 scatter plot.
In this study most of cells were either oocytes or primitive oocyte-like cells, and therefore the mathematical model developed is dominated by features that distinguish between oocytes and oocyte-like cells. As a consequence, the fibroblasts and hESCs do not distinguish themselves appreciably in this comparison. In cases like this, biologically relevant information may be hidden in higher order PCs. The oocytelike cells, hESCs, and fibroblasts were all found at high PC1 values, which reflects a shared high expression of the genes behind PC1 among them. Along PC3 the fibroblasts and hESCs clearly separated (Figure 4(b)). This suggests that they have different expression among the genes defining PC3. Moreover, primitive oocyte-like cells also separated along PC3 (Figure 4(b)). This suggests there are two kinds of 
oocyte-like cells that share features either with the hESCs or with the fibroblasts. Eight primitive oocyte-like cells shared features with the fibroblasts and were more "somatic," possibly, whereas ten primitive oocyte-like cells shared features with the hESCs and were putative stem cells. Primitive oocyte-like cells sharing features with the hESCs also shared features with three oocytes: two immature MI oocytes and one in vitro matured(IVM) oocyte, as seen in Figures 4 (c) and 4(d).

In hierarchical clustering (heatmaps), sixteen oocytes group together, while three oocytes (two immature MI oocytes and one in vitro matured(IVM) oocyte) cluster with seven primitive oocyte-like cells developed in vitro (Figure $4(\mathrm{~d})$ ). hESCs and fibroblasts cluster together mainly due to low expressions of the chosen genes.

3.4.2. Expression of Genes Characteristic of Pluripotent Stem Cells. Oocyte-like cells developed in vitro expressed 17 out of the 21 analyzed genes characteristic of pluripotent stem cells (Figure 5(a)). Primitive oocyte-like cells expressed KIT-LIG, OCT4A, NANOG, MYC, KLF4, SOX2, UTF1, TDGF1, CD9, LIN28, NANOS, CDH1, STAT3, MEST, CRKRS, STELLA, and GDF3 and did not express KIT, LIN28B, TERT, and REX1. Most of the 13 cells clustered together with the groups of 10 and 20 hESCs, as revealed by hierarchical clustering (dendrogram) (Figure 5(b)) and PCA (Figure 5(c)). Only five cells clustered with three outstanding oocytes (Figure 5).

Primitive oocyte-like cells developed in vitro expressed LIN28, NANOG, SOX-2, and UTF1 to significantly a greater extent and STELLA, CDH1, and CRKRS to significantly lesser extent than oocytes, as revealed by two-tailed Mann-Whitney test (Figure 6(a)). To keep the overall risk of false positive at $5 \%$, a threshold value of $P<0.00244$ was used to indicate significance. The $P$ values are presented in Table 3. KIT-LIG was the only gene not expressed in the oocytes. Primitive oocyte-like cells developed in vitro expressed $C D 9$, NANOS, STELLA, STAT3, UTF1, and LIN28 to significantly greater extents than the hESCs (Figure 6(b)). hESCs did not express KIT-LIG and REX1. Different from the primitive oocyte-like cells and hESCs, fibroblasts did not express KIT, KIT-LIG, GDF3, NANOG, UTF1, TDGF1, LIN28B, TERT, $C D H 1$, and $R E X 1$, which are characteristic of pluripotent stem cells (Figure 6(c)). Further, they did express NANOS, LIN28, STELLA, CD9, SOX-2, OCT4A, MEST, and STAT3 at a very low level, substantially less than the primitive oocyte-like cells (Figure 6(c); $P$ values in Table 3). Comparing all groups of cells statistically significant differences (Table 3 ) were found in the expression of KIT, STELLA, OCT4A, LIN28, NANOG, SOX-2, UTF1, TDGF1, LIN28B, TERT, CD9, NANOS, CDH1, STAT3, MEST, and CRKRS based on the One-Way ANOVA.

\subsubsection{Expression of Oocyte-Specific Genes in Comparison} with Nonfertilized Oocytes from the In Vitro Fertilization Programme. Primitive oocyte-like cells developed in vitro expressed 22 out of the 34 analyzed oocyte-specific genes (Figure 7(a)): GFRAa1, KIT-LIG, DNMT3B, DNMT1, ZP3, SCP1, SCP2, SCP3, CCNB1, FMN2, HIFOO, DMC1, BUB1, BUB3, STELLA, STAG3, SMC1A, BNC1, REC8, MSH5,
PRDM1/BLIMP1, and CD9 and did not express the twelve important oocyte- (germline-) specific genes: VASA, DAZL, KIT, BMP15, ZP1, ZP2, ZP4, NOBOX, NLRP5, MLH1, ZAR1, and FIGLA. As revealed by hierarchical clustering (Figure 7(b)) and PCA (Figure 7(c)), the oocytes form an independent cluster evidencing a distinct expression profile with the exception of two immature MI oocytes and one IVM oocyte. Positive control oocytes from the in vitro fertilization programme expressed all the oocyte-specific genes except KIT-LIG. They expressed BNC1 at a significantly higher level than in vitro developed oocyte-like cells (Table 3 ) according to the Mann-Whitney test (two-tailed). To keep the risk of false positive at 5\%, a threshold value of $P<0.00151$ was used. At this very conservative threshold differential expression of other genes was not significant.

Focusing on 13 oocyte-specific genes that are directly or indirectly involved in meiosis (SMC1A, SCP1, SCP2, SCP3, CCNB1, BUB3, MSH5, FMN2, HIFOO, MLH1, REC8, STAG3, and DMC1) we find that the primitive oocyte-like cells developed in vitro expressed twelve out of the 13 genes. Only the $M L H 1$ gene was not expressed (Figure 7(a)). In the primitive oocyte-like cells the meiotic gene MSH5 was expressed at a significantly lower level than in the nonfertilized oocytes from the in vitro fertilization programme, while REC8 was expressed at a significantly higher level (two-tailed MannWhitney test, significance threshold $P<0.00394 ; P$ values presented in Table 3). Differential expression of other genes was not statistically significant based on this conservative threshold. The gene expression levels (Ct values) of the primitive oocyte-like cells and of the oocytes matched very well, particularly for SCP1, SMC1A, and MSH5, whereas for the hESCs and the fibroblasts they did not (Figure 8). Although the primitive oocyte-like cells and the oocytes separate two distinct groups of cells based on the overall gene expression profile, as revealed by hierarchical clustering (Figure 7(b)), there are substantial similarities. The hESCs and the fibroblasts express meiotic genes at very low level. Seven genes (SCP2, SCP3, MSH5, FMN2, HIFOO, MLH, and STAG3) were not expressed at all in the hESCs, and another set of seven meiotic genes (SCP2, SCP3, MSH5, HIFOO, MLH1, STAG3, and $D M C 1$ ) was not expressed in the fibroblasts (Figure $7(\mathrm{a})$ ).

3.5. DAPI Staining the Cell Nuclei. Sixty-eight oocyte-like cells developed in vitro and collected from all patients were monitored after DAPI staining: 67 (98.5\%) cells were normal, mononuclear, and one cell (1.5\%) had two nuclei (Figure 9).

\section{Discussion}

This study confirms the existence of cells expressing several markers of pluripotency-putative stem cells-in the OSE layer of women with POF. In this study the putative ovarian stem cells were scraped from the ovarian surface epithelium of women with nonfunctional ovaries and cultured in vitro in the presence of follicular fluid from the in vitro fertilization programme. The added follicular fluid triggered development of stem cells into primitive oocyte-like cells, which expressed some markers of pluripotency and oocytes. 


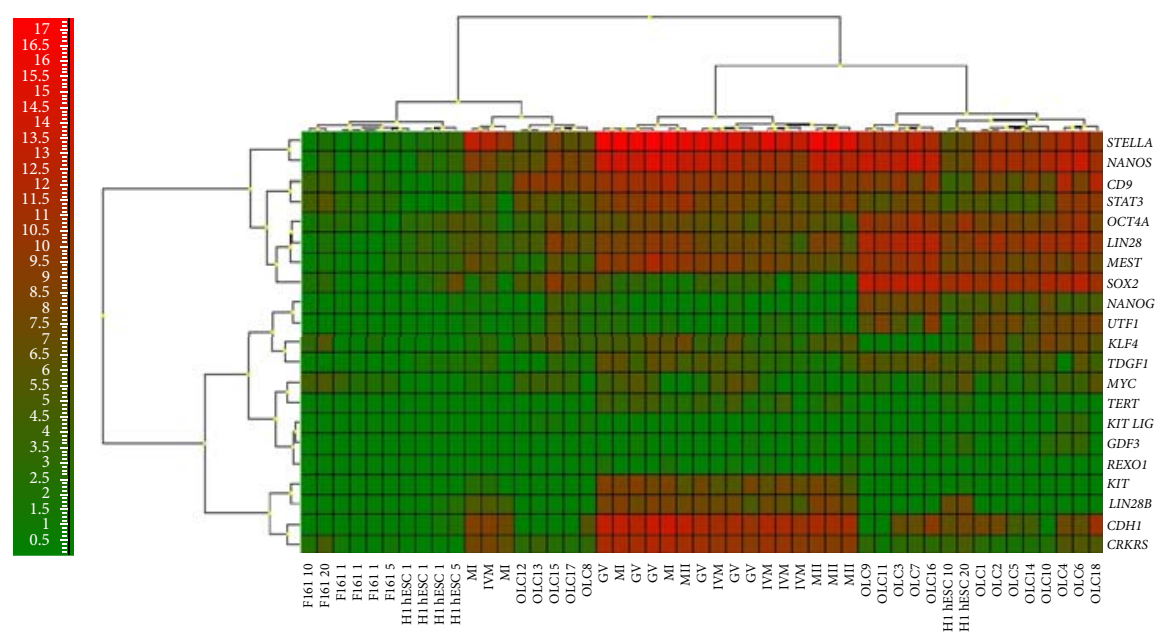

(a)

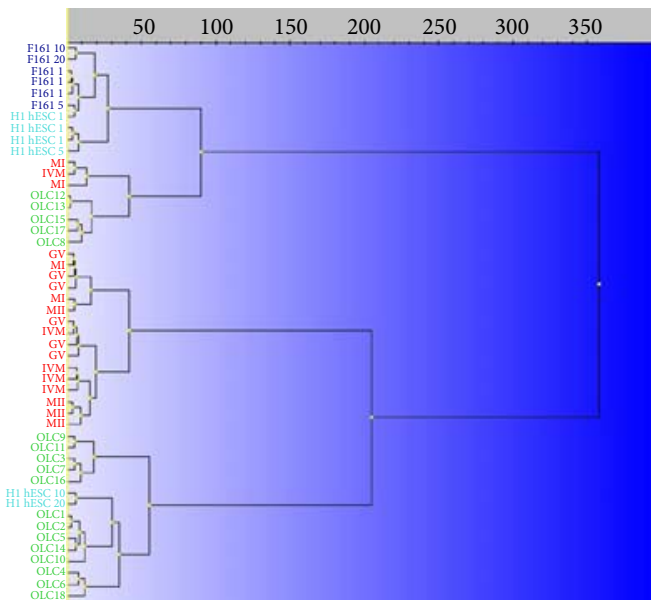

(b)

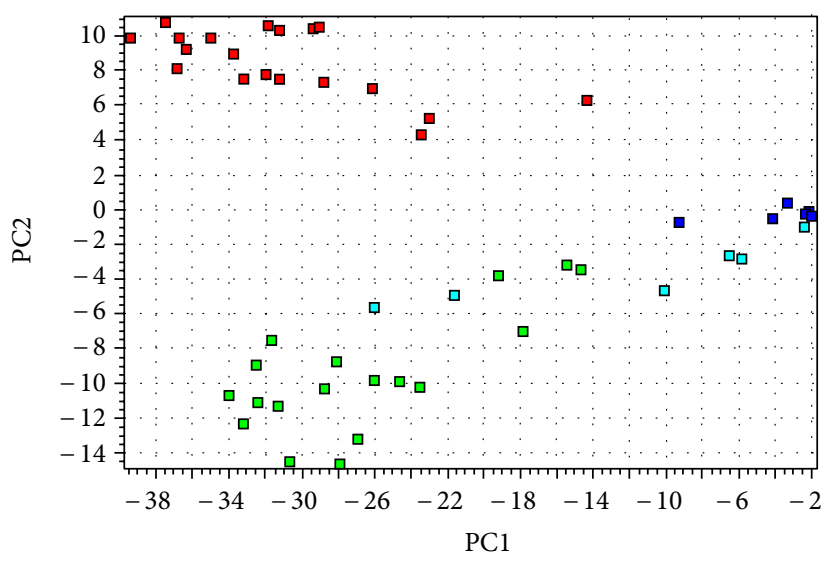

(c)

FIGURE 5: Single-cell gene expression profile of genes related to pluripotency in primitive oocyte-like cells (OLCs) developed in vitro. Comparison with human embryonic stem cells (H1 hESCs), nonfertilized oocytes from the in vitro fertilization programme (O) and fibroblasts (F161) revealed the expression of several genes related to pluripotency in oocyte-like cells. (a) Heatmap clustering. (b) Hierarchical clustering. (c) Principle component analysis (PC1 versus PC2). Legend of analyzed cells:OLC(1-18): oocyte-like cells developed in vitro; H1 hESC: human embryonic stem cells of line H1 (1: one cell, 5: five cells, 10: ten cells, and 20: twenty cells); F161: fibroblasts of F161 line (1: one cell, 5: five cells, 10: ten cells, and 20: twenty cells); MII: mature, metaphase II oocytes; IVM: immature, in vitro matured oocytes; MI: immature, metaphase I oocytes; GV: immature, germinal vesicle oocytes from the in vitro fertilization programme. Cell group colours: red: oocytes from the in vitro fertilization programme, green: oocyte-like cells, developed in vitro, aquamarine: hESCs, and dark blue: fibroblasts. 


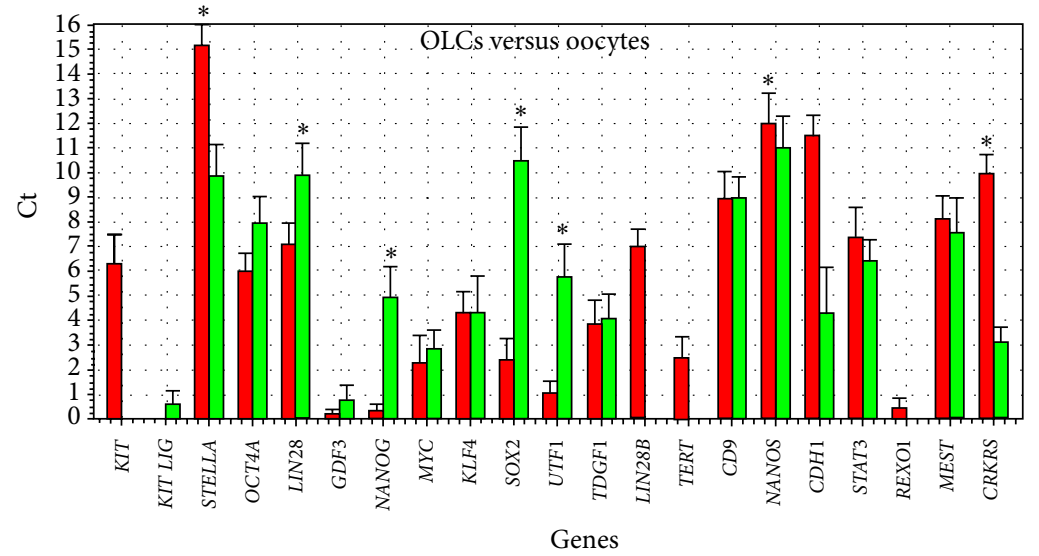

- Oocytes

r OLCs

(a)

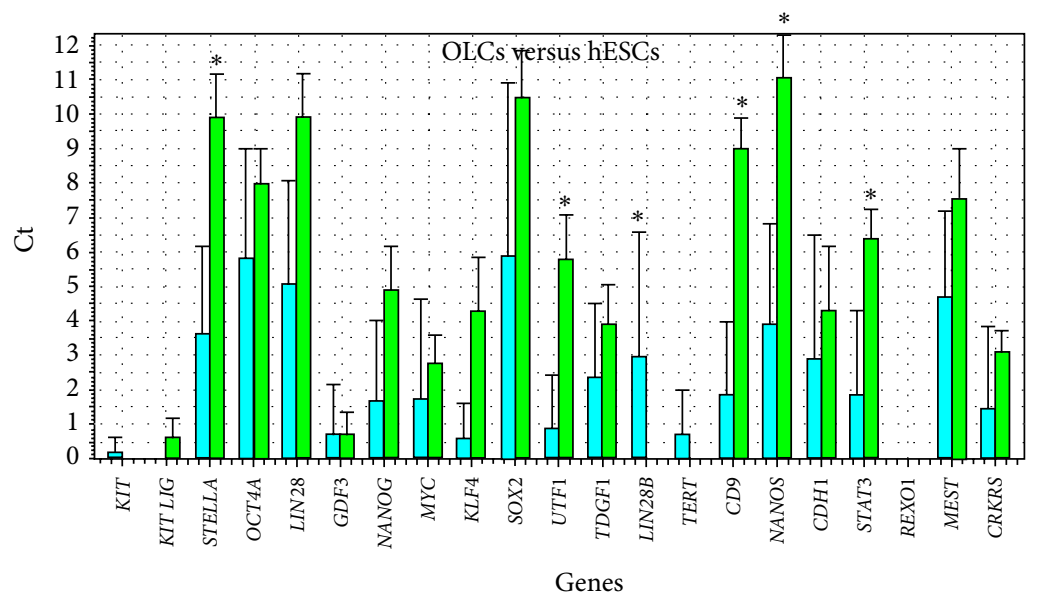

+ hESCs

Genes

- OLCs

(b)

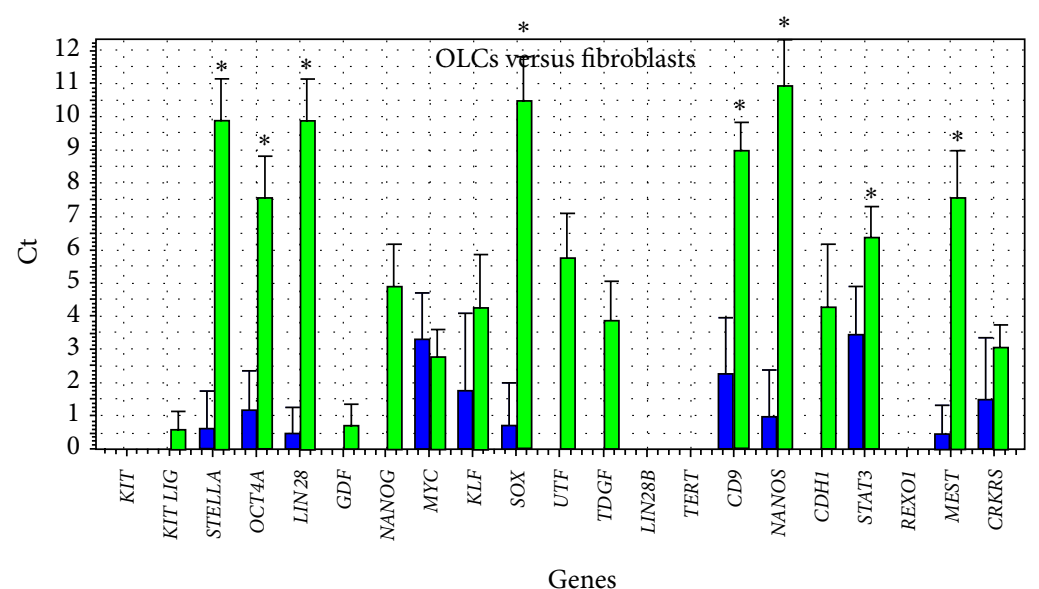

- Fibroblasts

Genes

r OLCs

(c)

FIGURE 6: Descriptive statistics of the expression of genes (Ct values), characteristic of pluripotent stem cells in primitive oocyte-like cells (OLCs), developed in vitro. (a) Comparison with oocytes. (b) Comparison with hESCs. (c) Comparison with fibroblasts. Cell group colours: green: oocyte-like cells, developed in vitro, red: oocytes from the in vitro fertilization programme, and dark blue: fibroblasts. Legend: * Statistically significant difference at $P<0.00244$ (Dunn-Bonferroni correction), as revealed using the two-tailed Mann-Whitney test. 


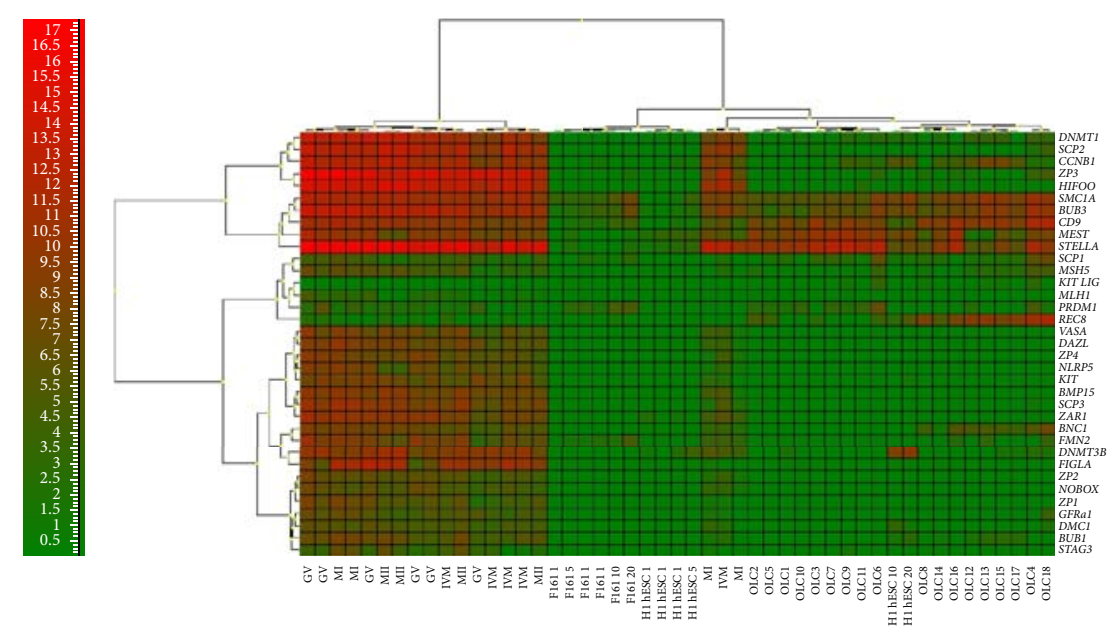

(a)

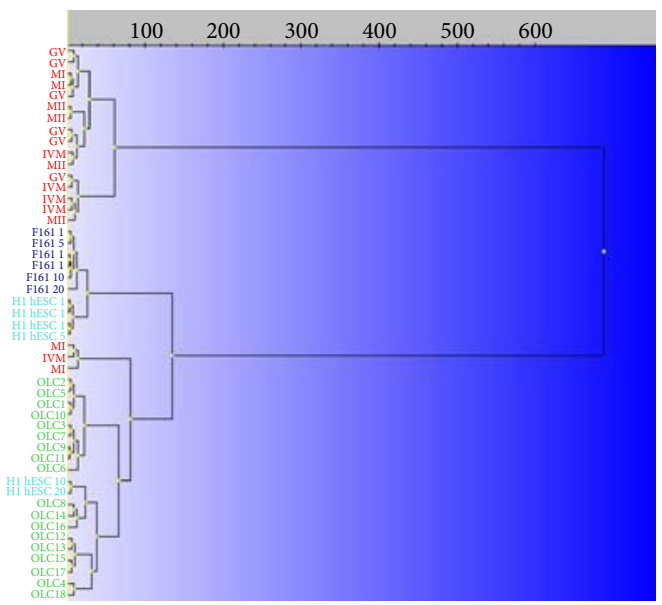

(b)

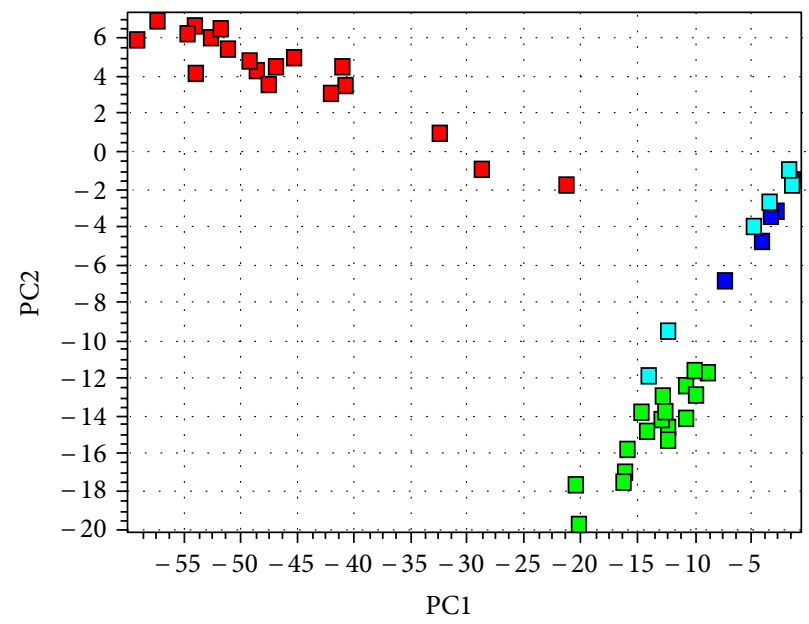

(c)

FIGURE 7: Single-cell gene expression profile of oocyte-specific genes in primitive oocyte-like cells developed in vitro (OLCs). Comparison with human embryonic stem cells (H1 hESCs), nonfertilized oocytes from the in vitro fertilization programme (O) and fibroblasts (F161) revealed the expression of several oocyte-specific genes in oocyte-like cells. (a) Heatmap clustering. (b) Hierarchical clustering. (c) Principle component analysis (PC1 versus PC2). Legend of analyzed cells: OLC(1-18): oocyte-like cells developed in vitro; O: oocytes; H1 hESC: human embryonic stem cells of line H1 (1: one cell, 5: five cells, 10: ten cells, and 20: twenty cells); F161: fibroblasts of F161 line. 


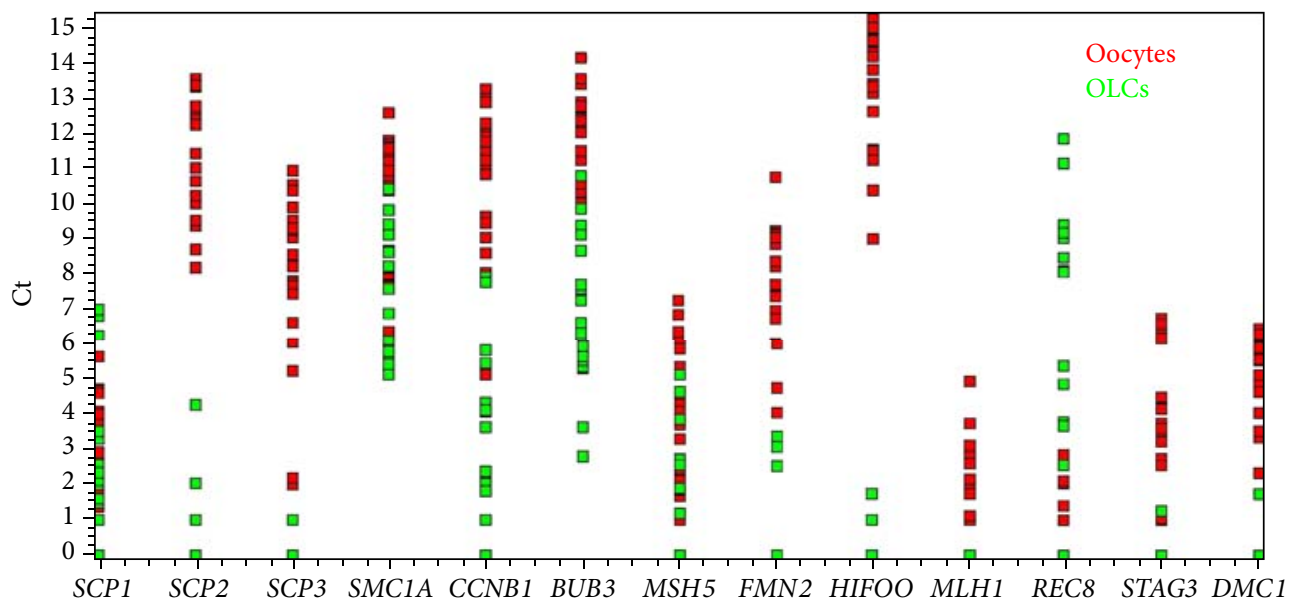

(a)

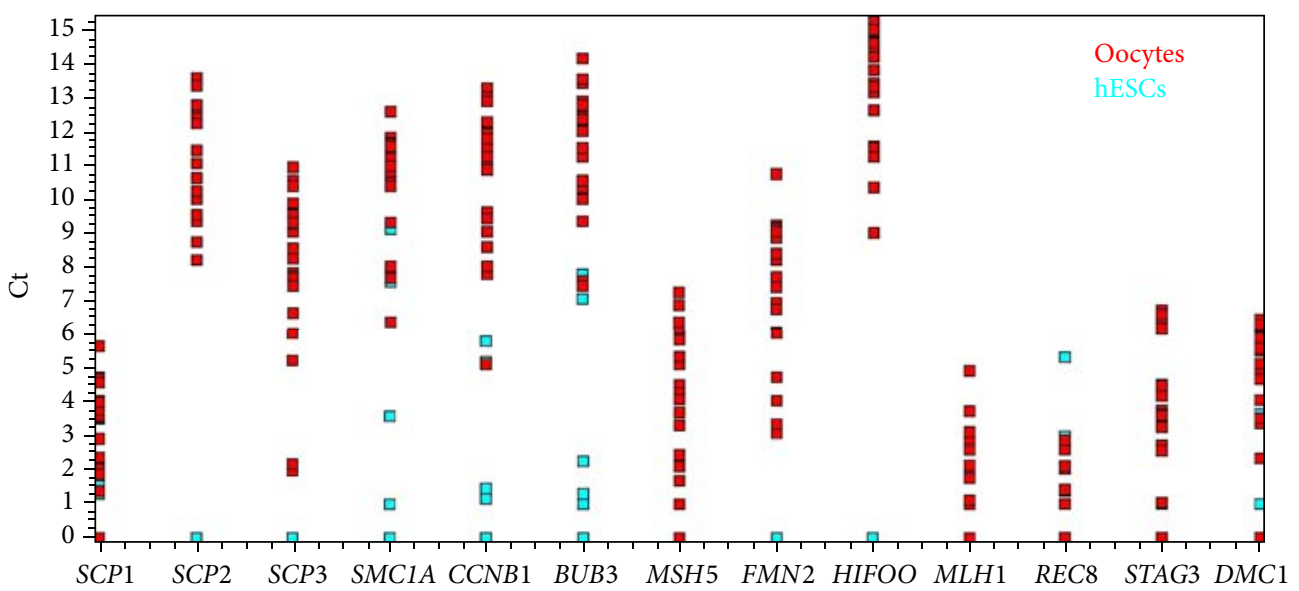

(b)

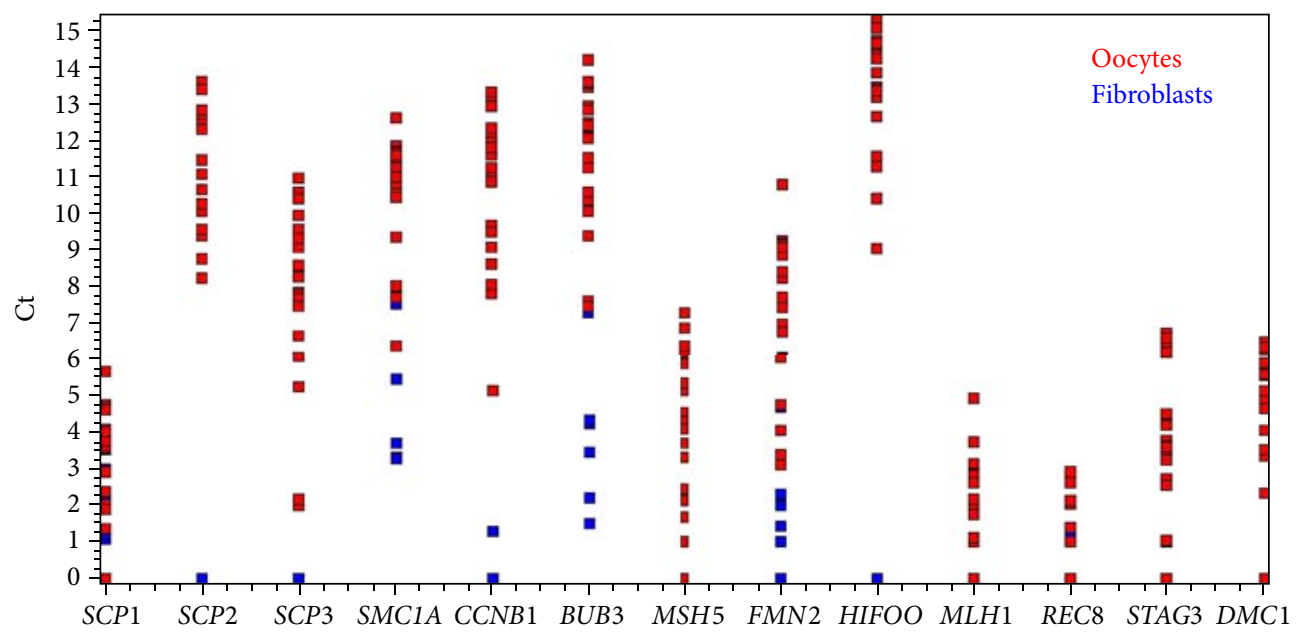

(c)

Figure 8: Expression of meiosis-related genes in oocyte-like cells developed in vitro. Primitive oocyte-like cells expressed the most, 12 out of 13 meiosis-related genes. In oocyte-like cells gene expressions fitted with oocyte gene expressions while in hESCs and fibroblasts they did not. Expression of meiosis-related genes (Ct values) presented in 2D plots: (a) oocytes (red) and oocyte-like cells (green); (b) oocytes (red) and hESCs (aquamarine); (c) oocytes (red) and fibroblasts (dark blue). 
TABle 3: $P$ values retrieved by statistical analyses of single-cell gene expressions in analyzed groups of cells.

\begin{tabular}{|c|c|c|}
\hline Statistical test & Compared cells & $P$ value \\
\hline \multicolumn{3}{|c|}{ Genes of pluripotency } \\
\hline $\begin{array}{l}\text { Two-tailed } \\
\text { Mann-Whitney test }\end{array}$ & OLCs versus oocytes & $\begin{array}{c}\text { LIN28 }(P=0.00078), \\
\text { STELLA }\left(P=1.0766 \times 10^{-6}\right), \\
\text { NANOG }\left(P=8.5203 \times 10^{-6}\right), \\
\text { SOX-2 }\left(P=2.2075 \times 10^{-7}\right), \\
\text { UTF1 }\left(P=1.1288 \times 10^{-5}\right), \\
\text { CDH1 }\left(P=1.0766 \times 10^{-6}\right), \\
\text { CRKRS }\left(P=2.2075 \times 10^{-7}\right)\end{array}$ \\
\hline $\begin{array}{l}\text { Two-tailed } \\
\text { Mann-Whitney test }\end{array}$ & OLCs versus hESCs & $\begin{array}{c}\text { CD9 }(P=0.00036), \\
\text { NANOS }(P=0.00097), \\
\text { STELLA }(P=0.00154), \\
\text { STAT3 }(P=0.00154), \\
\text { UTF1 }(P=0.00154), \\
\text { LIN28 }(P=0.00242)\end{array}$ \\
\hline $\begin{array}{l}\text { Two-tailed } \\
\text { Mann-Whitney test }\end{array}$ & OLCs versus fibroblasts & $\begin{array}{l}\text { NANOS }(P=0.00036), \\
\text { LIN28 }(P=0.00036), \\
\text { STELLA }(P=0.00036), \\
\text { CD9 }(P=0.00036) \\
\text { SOX-2 }(P=0.00036) \\
\text { OCT4A }(P=0.00036), \\
\text { MEST }(P=0.00060) \\
\text { STAT3 }(P=0.00242)\end{array}$ \\
\hline One-Way ANOVA & All types of cells & $\begin{array}{c}\text { KIT }\left(P \leq 1 \times 10^{-8}\right) \\
\text { STELLA }\left(P \leq 1 \times 10^{-8}\right) \\
\text { OCT4A }\left(P=6.86 \times 10^{-6}\right) \\
\text { LIN28 }\left(P \leq 1 \times 10^{-8}\right) \\
\text { NANOG }\left(P=1.3 \times 10^{-7}\right) \\
\text { SOX-2 }\left(P \leq 1 \times 10^{-8}\right) \\
\text { UTF1 }\left(P=1 \times 10^{-8}\right) \\
\text { TDGF1 }(P=0.00167408) \\
\text { LIN28B }\left(P \leq 1 \times 10^{-8}\right) \\
\text { TERT }\left(P \leq 1 \times 10^{-8}\right) \\
\text { CD9 }\left(P \leq 1 \times 10^{-8}\right) \\
\text { NANOS }\left(P \leq 1 \times 10^{-8}\right) \\
\text { CDH1 }\left(P \leq 1 \times 10^{-8}\right) \\
\text { STAT3 }\left(P=4.67 \times 10^{-6}\right) \\
\text { MEST }\left(P=5.7 \times 10^{-7}\right) \\
\text { CRKRS }\left(P \leq 1 \times 10^{-8}\right)\end{array}$ \\
\hline \multicolumn{3}{|c|}{ Oocyte-specific genes } \\
\hline $\begin{array}{l}\text { Two-tailed } \\
\text { Mann-Whitney test }\end{array}$ & OLCs versus oocytes & $B N C 1(P=0.00011)$ \\
\hline \multicolumn{3}{|c|}{ Genes of meiosis } \\
\hline $\begin{array}{l}\text { Two-tailed } \\
\text { Mann-Whitney test }\end{array}$ & OLCs versus oocytes & $\begin{aligned} \text { MSH5 }(P & =0.00204) \\
R E C 8 & (P=0.00166)\end{aligned}$ \\
\hline
\end{tabular}

Legend: OLCs: oocyte-like cells; hESCs: human embryonic stem cells.

Follicular fluid retrieved at the ultrasound-guided oocyte aspiration in the in vitro fertilization programme contains several substances important for oocyte growth and maturation including high levels of hormones [30]: estrogens, progesterone and FSH, androgens, proteins [31], and amino acids [31], a high concentration of lipids including free cholesterol and meiosis-activating sterol (FF-MAS) [32, 33], and growth factors [34]. Many of these substances are important for oocyte growth and maturation.
The culture medium with added follicular fluid used in this study was characterized by very high concentrations of estradiol and progesterone. The high concentrations of these reproductive hormones in follicular fluid were normal and resulted from the ovarian hormonal stimulation protocol, which was routinely used in a patient to retrieve oocytes for in vitro fertilization. The OSE cell cultures including oocytelike cells depleted/converted these hormones from the culture medium. It has already been found that follicular fluid can 


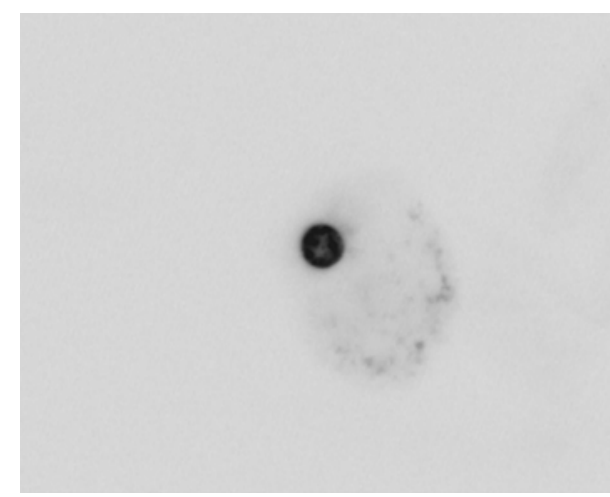

(a)

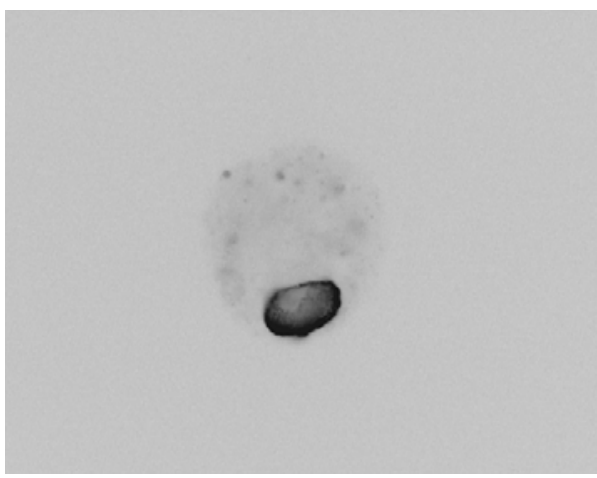

(c)

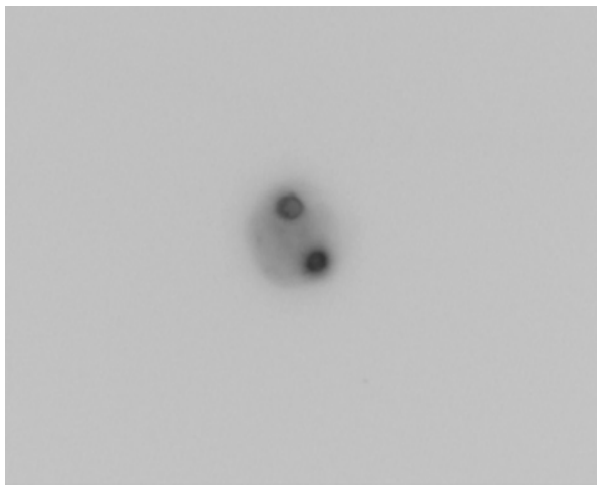

(e)

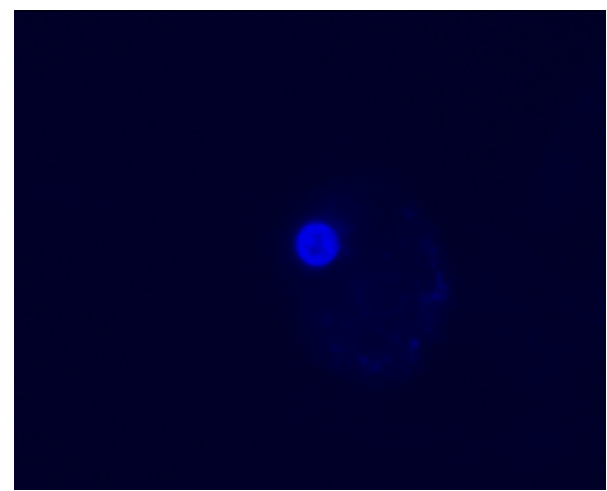

(b)

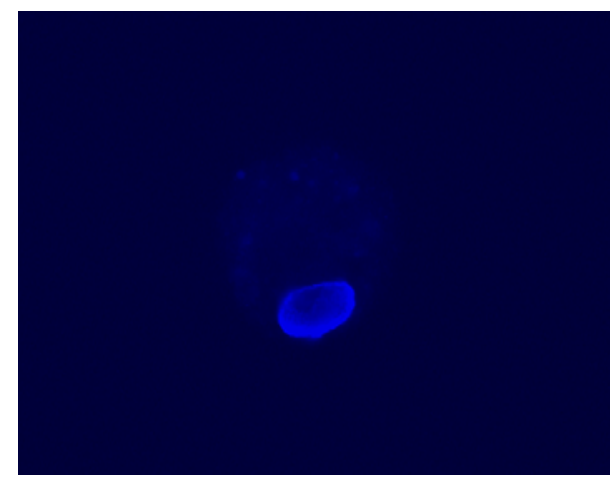

(d)

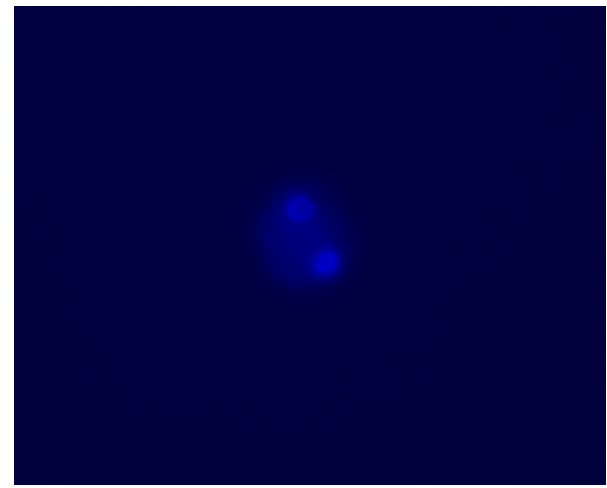

(f)

FIGURE 9: Nuclei of in vitro developed primitive oocyte-like cells monitored after DAPI staining. DAPI staining confirmed mononuclear and binuclear cells: ((a)-(d)) two normal mononuclear primitive oocyte-like cells. ((e), (f)) One abnormal primitive oocyte-like cell with two nuclei. (Light and fluorescence microscope, magnification 400x.)

induce OSE cell proliferation, but estradiol and progesterone did not induce the cell proliferation; it was concluded that follicular fluid directly stimulates OSE cell proliferation by nonsteroidal mitogens [35]. On the other hand several studies confirmed that estradiol has a positive impact on the human oocyte growth and maturation in vivo and in vitro. It has already been published that oocyte-like cell development in vitro can be triggered by weak estrogenic activity of phenol red in the cell culture medium $[18,25]$. The estradiol can directly influence the quality of maturing human oocytes by steroid action on the cell surface via $\mathrm{Ca}^{2+}$ as a second messenger and contribute to the oocyte potential for fertilization and early postfertilization development [36]. In the in vitro fertilization programme estradiol and testosterone levels in follicular fluid may be used as predictive parameters of oocyte maturity [37]. In the follicular phase of menstrual cycle, follicles which contained a healthy but not degenerative oocyte had a significantly higher level of estradiol in the follicular fluid [38]. The oocytes which gave rise to successful pregnancies were obtained from follicles which contained greater concentrations of estradiol than did oocytes from which pregnancy did not result [39]. Moreover, transient 
estradiol supplementation improved the oocyte in vitro maturation rate and subsequent developmental competence in porcine [40] and white-tailed deer oocytes [41]. Similarly, estradiol and progesterone improved in vitro cytoplasmic maturation and developmental competence of oocytes from unstimulated prepubertal and adult rhesus monkeys [42]. Based on all this knowledge, it is not excluded that estradiol alone or in combination with other substances from the follicular fluid was involved in in vitro development of primitive oocyte-like cells in this study.

The majority of primitive oocyte-like cells developed in vitro were normally mononuclear and expressed several genes characteristic of pluripotent stem cells and of oocytes based on single-cell gene expression profiling. They express most of the genes of pluripotency tested and several oocyte-specific genes, including genes related to epigenetic regulation (e.g., $D N M T 1, D N M T 3 B)$, zona pellucida structure (ZP3), and late meiotic genes (e.g., SCP1, SCP2, and SCP3). Although these genes were expressed at a significantly lower extent than in nonfertilized oocytes from the in vitro fertilization programme, there was a subgroup of immature or in vitro matured oocytes that clustered together with oocyte-like cells and not with other oocytes based on their gene expression profiles.

Although primitive oocyte-like cells less expressed a majority of the analyzed genes involved in meiosis ( $S C P 1$, SCP2, SCP3, SMC1A, CCNB1, BUB3, MSH5, FMN2, HIFOO, $M L H 1, R E C 8, S T A G 3$, and DMC1), they still expressed REC8 at a significantly higher level than the oocytes. REC8 plays an important role in sister chromatid cohesion during meiosis [43]. In spite of that, oocyte-like cells did not express some important oocyte-specific genes, such as VASA, DAZL, and FIGLA, and therefore exhibited the characteristics of pluripotent stem cells more than of competent oocytes. As shown in the model of human and mouse ESCs, the expression of germ cell-specific genes (including VASA) in oocytelike cells developed in vitro can be regulated by different culture conditions $[7,10]$, for example, by the addition of retinoic acid into the culture medium that regulates germ cell differentiation through a Smad-dependent pathway [44]; therefore the possibilities of in vitro "oogenesis" in this study were far from being exhausted. As previously proposed, oocyte-like cells developed in vitro could also be matured in vivo by transplantation into other organs, tissues, or ovarian biopsies $[5,23]$; it may be possible to autotransplant the oocyte-like cells to in vivo direct their growth, maturity, and function or perhaps to "awaken" the ovaries in women with severe ovarian infertility, if sure that teratoma would not form.

The results of this study are in accordance with findings of White et al. [23], who published the existence of rare mitotically active cells-stem cells-with a gene expression profile that is consistent with primitive germ cells in ovarian cortical tissue of women in reproductive period of age. These cells were able to generate oocyte-like cells in vitro.

The results of our study show that the adult OSE in women with nonfunctional ovaries may be an important source of putative stem cells.

\section{Conclusions}

The addition of donated follicular fluid, rich in substances for oocyte growth and maturation, to the culture medium triggers development of putative stem cells from the ovarian surface epithelium of women with nonfunctional ovaries into the direction of primitive oocyte-like cells that express several genes related to pluripotency and oocytes, but are more "stem cells" than real "oocytes" at present.

\section{Conflict of Interests}

The authors declare that they have no conflict of interests.

\section{Authors' Contribution}

I. Virant-Klun was a leader and coordinator of the research project. She performed all cell cultures, cultured oocyte-like cells, and wrote this paper. T. Skutella provided single-cell gene expression analyses by the Fluidigm system and read this paper. M. Kubista performed biostatistics of single-cell gene expression profiling and read this paper. A. Vogler surgically retrieved ovarian tissue to be researched. J. Sinkovec performed all histopathological evaluations of ovarian tissue in patients included into this study. H. Meden-Vrtovec included her patients with premature ovarian failure into this study.

\section{Acknowledgments}

The authors are grateful to all patients who kindly collaborated in this study, Professor Antonin Bukovsky, Institute for Biotechnology, Prague, Czech Republic, for teaching the first steps in ovarian surface epithelium cell culture, Ms. Sabine Conrad, MTA, University of Tuebingen, Germany, for her technical assistance in the Fluidigm analyses, and Mr. Benjamin Klun, student of medicine, for assistance in the technical preparation of the figures for this paper. They also greatly acknowledge the Slovenian Research Agency (ARRS, Grant J3-0415 to I. Virant-Klun) and the German Federal Ministry of Education and Research (BMBF, Grant 01GN1001 to T. Skutella) for financial support and all others who supported this research.

\section{References}

[1] K. Hübner, G. Fuhrmann, L. K. Christenson et al., "Derivation of oocytes from mouse embryonic stem cells," Science, vol. 300, no. 5623, pp. 1251-1256, 2003.

[2] A. T. Clark, M. S. Bodnar, M. Fox et al., "Spontaneous differentiation of germ cells from human embryonic stem cells in vitro," Human Molecular Genetics, vol. 13, no. 7, pp. 727-739, 2004.

[3] O. Lacham-Kaplan, H. Chy, and A. Trounson, "Testicular cell conditioned medium supports differentiation of embryonic stem cells into ovarian structures containing oocytes," Stem Cells, vol. 24, no. 2, pp. 266-273, 2006.

[4] I. Novak, D. A. Lightfoot, H. Wang, A. Eriksson, E. Mahdy, and C. Höög, "Mouse embryonic stem cells form follicle-like ovarian structures but do not progress through meiosis," Stem Cells, vol. 24, no. 8, pp. 1931-1936, 2006. 
[5] C. R. Nicholas, K. M. Haston, A. K. Grewall, T. A. Longacre, and R. A. Reijo Pera, "Transplantation directs oocyte maturation from embryonic stem cells and provides a therapeutic strategy for female infertility," Human Molecular Genetics, vol. 18, no. 22, pp. 4376-4389, 2009.

[6] K. Zou, Z. Yuan, Z. Yang et al., "Production of offspring from a germline stem cell line derived from neonatal ovaries," Nature Cell Biology, vol. 11, no. 5, pp. 631-636, 2009.

[7] G. B. Zhou, Q. G. Meng, and N. Li, "In vitro derivation of germ cells from embryonic stem cells in mammals," Molecular Reproduction and Development, vol. 77, no. 7, pp. 586-594, 2010.

[8] O. E. Psathaki, K. Hübner, D. Sabour et al., "Ultrastructural characterization of mouse embryonic stem cell-derived oocytes and granulosa cells," Stem Cells and Development, vol. 20, no. 12, pp. 2205-2215, 2011.

[9] M. Richards, C. Y. Fong, and A. Bongso, "Comparative evaluation of different in vitro systems that stimulate germ cell differentiation in human embryonic stem cells," Fertility and Sterility, vol. 93, no. 3, pp. 986-994, 2010.

[10] F. D. West, M. I. Roche-Rios, S. Abraham et al., "KIT ligand and bone morphogenetic protein signaling enhances human embryonic stem cell to germ-like cell differentiation," Human Reproduction, vol. 25, no. 1, pp. 168-178, 2010.

[11] J. V. Medrano, C. Ramathal, H. N. Nguyen, C. Simon, and R. A. Reijo Pera, "Divergent RNA-binding proteins, DAZL and VASA, induce meiotic progression in human germ cells derived in vitro," Stem Cells, vol. 30, no. 3, pp. 441-451, 2012.

[12] X. Cheng, S. Chen, X. Yu, P. Zheng, and H. Wang, "BMP15 gene is activated during human amniotic fluid stem cell differentiation into oocyte-like cells," DNA and Cell Biology, vol. 31, no. 7, pp. 1198-1204, 2012.

[13] P. W. Dyce, L. Wen, and J. Li, "In vitro germline potential of stem cells derived from fetal porcine skin," Nature Cell Biology, vol. 8, no. 4, pp. 384-390, 2006.

[14] P. W. Dyce, W. Shen, E. Huynh et al., "Analysis of oocyte-like cells differentiated from porcine fetal skin-derived stem cells," Stem Cells and Development, vol. 20, no. 5, pp. 809-819, 2011.

[15] S. Danner, J. Kajahn, C. Geismann, E. Klink, and C. Kruse, "Derivation of oocyte-like cells from a clonal pancreatic stem cell line," Molecular Human Reproduction, vol. 13, no. 1, pp. 1120, 2007.

[16] S. P. Gong, S. T. Lee, E. J. Lee et al., "Embryonic stem celllike cells established by culture of adult ovarian cells in mice," Fertility and Sterility, vol. 93, no. 8, pp. 2594-2601, 2010.

[17] J. Pacchiarotti, C. Maki, T. Ramos et al., "Differentiation potential of germ line stem cells derived from the postnatal mouse ovary," Differentiation, vol. 79, no. 3, pp. 159-170, 2010.

[18] A. Bukovsky, M. Svetlikova, and M. R. Caudle, "Oogenesis in cultures derived from adult human ovaries," Reproductive Biology and Endocrinology, vol. 3, p. 17, 2005.

[19] I. Virant-Klun, N. Zech, P. Rozman et al., "Putative stem cells with an embryonic character isolated from the ovarian surface epithelium of women with no naturally present follicles and oocytes," Differentiation, vol. 76, no. 8, pp. 843-856, 2008.

[20] I. Virant-Klun, P. Rožman, B. Cvjeticanin et al., "Parthenogenetic embryo-like structures in the human ovarian surface epithelium cell culture in postmenopausal women with no naturally present follicles and oocytes," Stem Cells and Development, vol. 18, no. 1, pp. 137-150, 2009.

[21] I. Virant-Klun, T. Skutella, M. Stimpfel, and J. Sinkovec, "Ovarian surface epithelium in patients with severe ovarian infertility: a potential source of cells expressing markers of pluripotent/multipotent stem cells," Journal of Biomedicine and Biotechnology, vol. 2011, Article ID 381928, 2011.

[22] S. Parte, D. Bhartiya, J. Telang et al., "Detection, characterization, and spontaneous differentiation in vitro of very small embryonic-like putative stem cells in adult mammalian ovary," Stem Cells and Development, vol. 20, no. 80, pp. 1451-1464, 2011.

[23] Y. A. White, D. C. Woods, Y. Takai, O. Ishihara, H. Seki, and J. L. Tilly, "Oocyte formation by mitotically active germ cells purified from ovaries of reproductive-age women," Nature Medicine, vol. 18, no. 3, pp. 413-421, 2012.

[24] D. Goswami and G. S. Conway, "Premature ovarian failure," Hormone Research, vol. 68, no. 4, pp. 196-202, 2007.

[25] Y. Berthois, J. A. Katzenellenbogen, and B. S. Katzenellenbogen, "Phenol red in tissue culture media is a weak estrogen: implications concerning the study of estrogen-responsive cells in culture," Proceedings of the National Academy of Sciences of the United States of America, vol. 83, no. 8, pp. 2496-2500, 1986.

[26] M. Bengtsson, A. Ståhlberg, P. Rorsman, and M. Kubista, "Gene expression profiling in single cells from the pancreatic islets of Langerhans reveals lognormal distribution of mRNA levels," Genome Research, vol. 15, no. 10, pp. 1388-1392, 2005.

[27] A. Raj, C. S. Peskin, D. Tranchina, D. Y. Vargas, and S. Tyagi, "Stochastic mRNA synthesis in mammalian cells," PLoS Biology, vol. 4, no. 10, p. e309, 2006.

[28] A. Ståhlberg, D. Andersson, J. Aurelius et al., "Defining cell populations with single-cell gene expression profiling: correlations and identification of astrocyte subpopulations," Nucleic Acids Research, vol. 39, no. 4, p. e24, 2011.

[29] A. Bergkvist, V. Rusnakova, R. Sindelka et al., "Gene expression profiling-clusters of possibilities," Methods, vol. 50, no. 4, pp. 323-335, 2010.

[30] I. J. Duijkers, W. N. Willemsen, H. M. Hollanders, C. J. Hamilton, C. M. Thomas, and H. M. Vemer, "Follicular fluid hormone concentrations after ovarian stimulation using gonadotropin preparations with different FSH/LH ratios. II. Comparison of hMG and recombinant FSH," International Journal of Fertility and Women's Medicine, vol. 42, no. 6, pp. 431-435, 1997.

[31] A. Velazquez, A. Reyes, J. Chargoy, and A. Rosado, "Amino acid and protein concentrations of human follicular fluid," Fertility and Sterility, vol. 28, no. 1, pp. 96-100, 1977.

[32] E. V. Bokal, K. F. Tacer, M. Vrbnjak et al., "Follicular sterol composition in gonadotrophin stimulated women with polycystic ovarian syndrome," Molecular and Cellular Endocrinology, vol. 249, no. 1-2, pp. 92-98, 2006.

[33] J. Smitz, H. M. Picton, P. Platteau et al., "Principal findings from a multicenter trial investigating the safety of follicularfluid meiosis-activating sterol for in vitro maturation of human cumulus-enclosed oocytes," Fertility and Sterility, vol. 87, no. 4, pp. 949-964, 2007.

[34] U. Ulug, E. Turan, S. B. Tosun, H. F. Erden, and M. Bahceci, "Comparison of preovulatory follicular concentrations of epidermal growth factor, insulin-like growth factor-I, and inhibins $\mathrm{A}$ and $\mathrm{B}$ in women undergoing assisted conception treatment with gonadotropin-releasing hormone $(\mathrm{GnRH})$ agonists and GnRH antagonists," Fertility and Sterility, vol. 87, no. 4, pp. 995998, 2007.

[35] L. K. Doyle and F. X. Donadeu, "Regulation of the proliferative activity of ovarian surface epithelial cells by follicular fluid," Animal Reproduction Science, vol. 114, no. 4, pp. 443-448, 2009.

[36] J. Tesarik and C. Mendoza, "Nongenomic effects of $17 \beta$ estradiol on maturing human oocytes: relationship to oocyte 
developmental potential," Journal of Clinical Endocrinology and Metabolism, vol. 80, no. 4, pp. 1438-1443, 1995.

[37] L. O. Costa, M. C. Mendes, R. A. Ferriani, M. D. Moura, R. M. Reis, and M. F. Silva de Sá, "Estradiol and testosterone concentrations in follicular fluid as criteria to discriminate between mature and immature oocytes," Brazilian Journal of Medical and Biological Research, vol. 37, no. 11, pp. 1747-1755, 2004.

[38] K. Tsuji, M. Sowa, and R. Nakano, "Relationship among the status of the human oocyte, the $17 \beta$-estradiol concentration in the antral fluid and the follicular size," Endocrinologia Japonica, vol. 30, no. 2, pp. 251-254, 1983.

[39] R. S. Carson, A. O. Trounson, and J. K. Findlay, "Successful fertilisation of human oocytes in vitro: concentration of estradiol-17 $\beta$, progesterone and androstenedione in the antral fluid of donor follicles," Journal of Clinical Endocrinology and Metabolism, vol. 55, no. 4, pp. 798-800, 1982.

[40] J. S. Kim, B. S. Song, S. R. Lee et al., "Supplementation with estradiol-17 $\beta$ improves porcine oocyte maturation and subsequent embryo development," Fertility and Sterility, vol. 95, no. 8, pp. 2582-2584, 2011.

[41] B. Siriaroonrat, P. Comizzoli, N. Songsasen, S. L. Monfort, D. E. Wildt, and B. S. Pukazhenthi, "Oocyte quality and estradiol supplementation affect in vitro maturation success in the whitetailed deer (Odocoileus virginianus)," Theriogenology, vol. 73, no. 1, pp. 112-119, 2010.

[42] P. Zheng, W. Si, B. D. Bavister, J. Yang, C. Ding, and W. Ji, "17 $\beta$-Estradiol and progesterone improve in-vitro cytoplasmic maturation of oocytes from unstimulated prepubertal and adult rhesus monkeys," Human Reproduction, vol. 18, no. 10, pp. 21372144, 2003.

[43] R. Garcia-Cruz, M. A. Brieño, I. Roig et al., "Dynamics of cohesin proteins REC8, STAG3, SMC1 $\beta$ and SMC3 are consistent with a role in sister chromatid cohesion during meiosis in human oocytes," Human Reproduction, vol. 25, no. 9, pp. 23162327, 2010.

[44] W. Chen, W. Jia, K. Wang et al., "Retinoic acid regulates germ cell differentiation in mouse embryonic stem cells through a Smad-dependent pathway," Biochemical and Biophysical Research Communications, vol. 418, no. 3, pp. 571-577, 2012. 

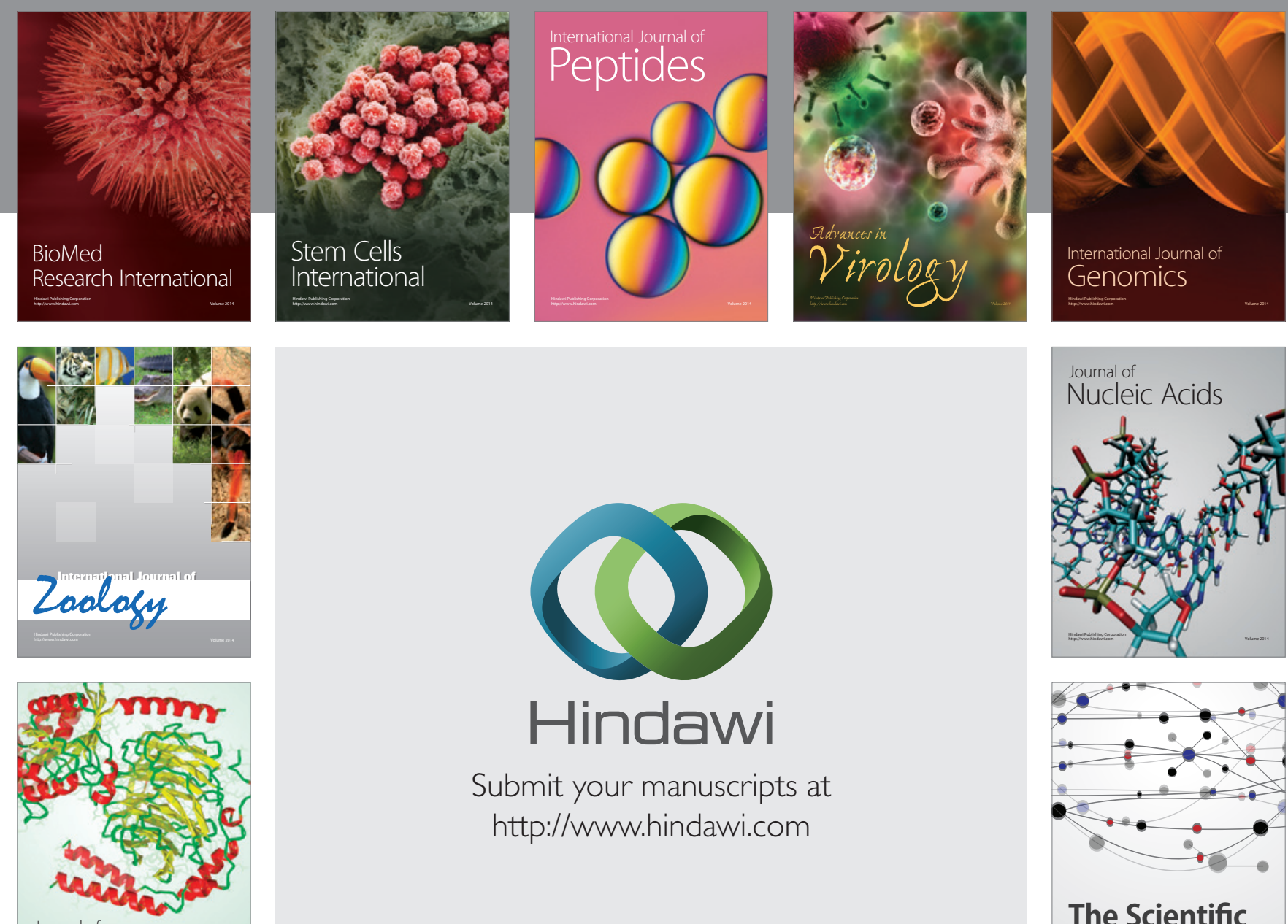

Submit your manuscripts at

http://www.hindawi.com

Journal of
Signal Transduction
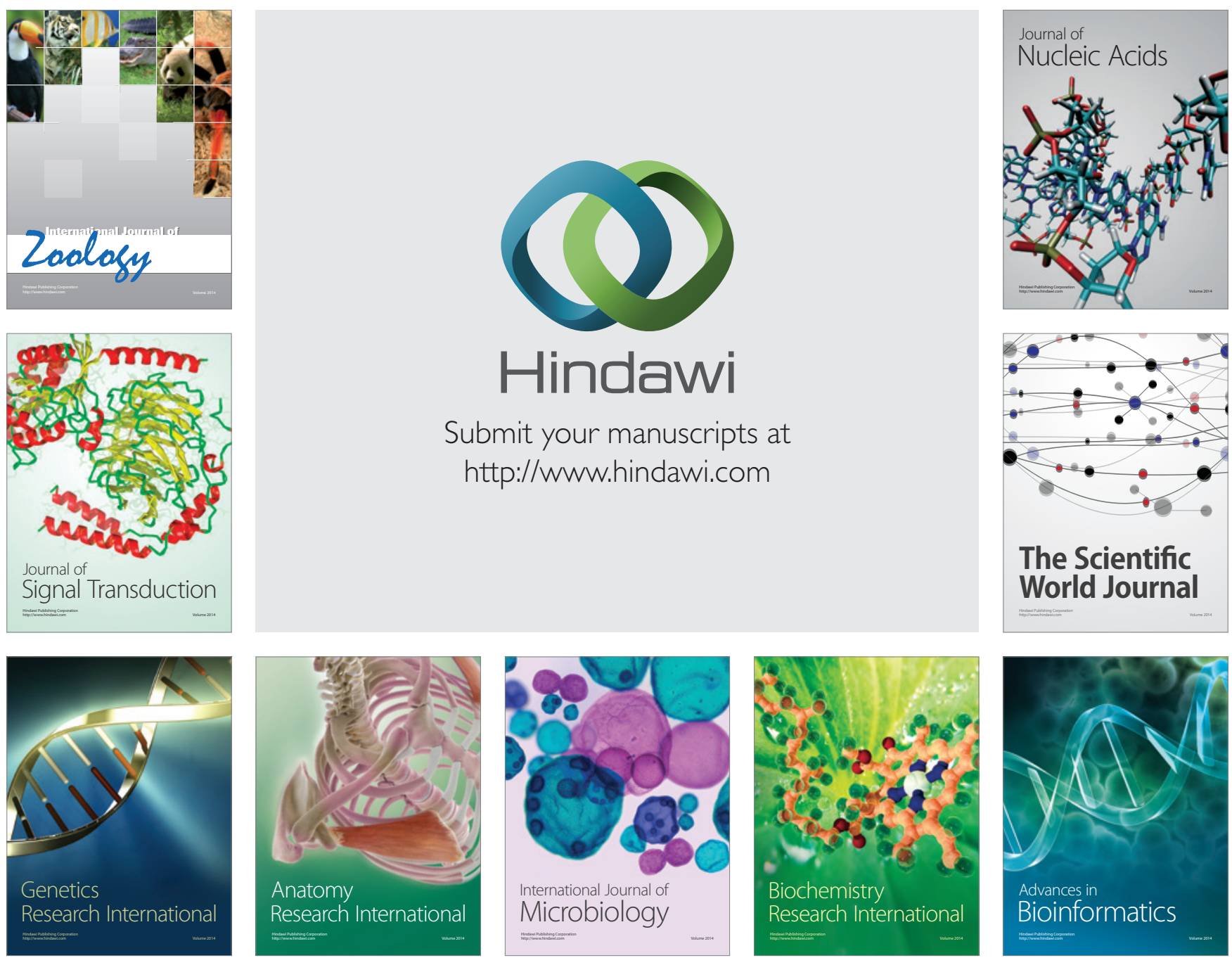

The Scientific World Journal
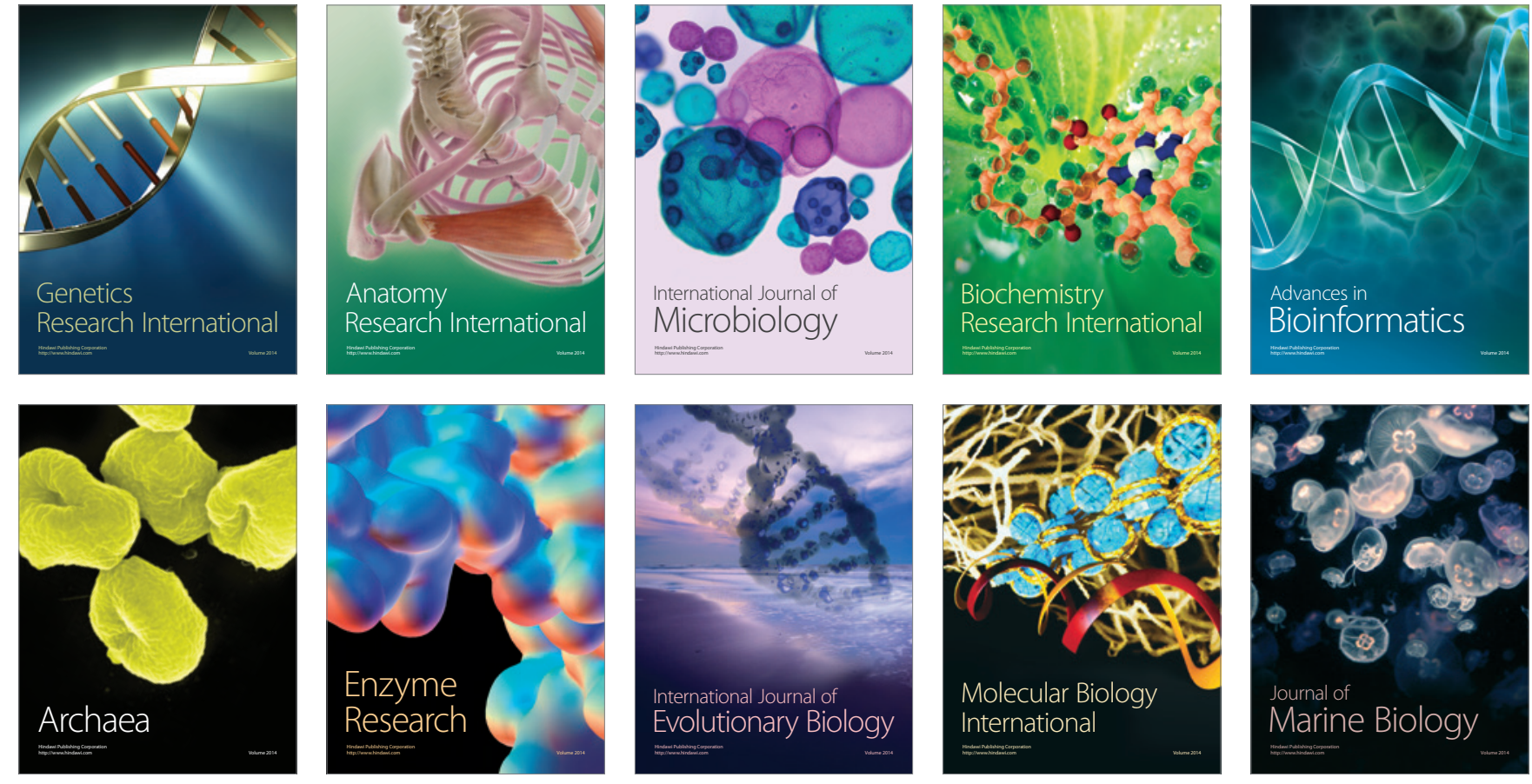